\title{
A importância estratégica do conhecimento do território na formação de um sistema defensivo: o caso de Sintra (Portugal) durante o Período Islâmico*
}

\begin{abstract}
Resumo
Focando o exemplo de Sintra durante o Período Islâmico, procura-se compreender como o conhecimento do território pesou na estratégia de edificação de fortificações e de estruturas de vigilância que permitiam a defesa militar e que faziam parte do sistema defensivo do distrito de Lisboa. A metodologia seguida consiste no cruzamento de dados entre as fontes históricas, arqueológicas, a toponímia e o reconhecimento geográfico. Os resultados obtidos mostram que Sintra, para além de dois castelos e de um ribat, teve outras estruturas defensivas e postos de vigilância que possibilitavam a comunicação com outros locais a longa distância e que marcavam a paisagem cultural marítima. A investigação permite concluir que a estruturação deste sistema defensivo implicou um planejamento estratégico baseado no estudo das diferentes combinações geográficas, das relações entre os povoados, das vias de comunicação, dos portos e ancoradouros, sendo que alguns locais importantes já teriam sido utilizados em épocas anteriores.
\end{abstract}

Palavras-chave: geografia, planeamento estratégico, defesa militar.

Referencia para citar este artículo: OLIVEIRA BORGES, Marco (2017). “A importância estratégica do conhecimento do território na formação de um sistema defensivo: o caso de Sintra (Portugal) durante o Período Islâmico". En Anuario de Historia Regional y de las Fronteras. 22 (2). pp. 17-48.

Marco Oliveira Borges: Actualmente, é bolseiro de doutoramento pela Fundação para a Ciência e a Tecnologia (SFRH/BD/52282/2013), Portugal. Licenciado em História, pós-graduado em História dos Descobrimentos e da Expansão e mestre em História Marítima pela Faculdade de Letras da Universidade de Lisboa, Portugal. Investigador associado do Centro de História e do Centro de Estudos Geográficos da Universidade de Lisboa, bem como membro correspondente da Academia de Marinha, Portugal. Correo electrónico: marcoliveiraborges@gmail.com. Código ORCID: 0000-0002-1547-4554.

\footnotetext{
* Este artigo resulta de investigações pessoais que têm vindo a ganhar forma desde 2009, no âmbito da ligação à Universidade de Lisboa, visando compreender a militarização, a defesa costeira e o povoamento na área ocidental do distrito de Lisboa durante o Período Islâmico.
} 


\title{
The Strategic Importance of Knowledge of the Territory in the Formation of a Defensive System: The Case of Sintra (Portugal) During the Islamic Period
}

\begin{abstract}
Focusing on the example of Sintra during the Islamic period, we seek to understand how the knowing of the territory weighed in the strategy for the construction of fortifications and surveillance structures that allowed for the military defence and that were part of the defensive system of the Lisbon region. The methodology used consists on the crossing of data between historical and archaeological sources, toponymical and geographical recognition. The results show that Sintra, besides two castles and a ribat, will have had other defensive structures and checkpoints that allowed communication with other distant places and marked the maritime cultural landscape. This investigation allows to conclude that the structuring of this defensive system implied a strategic planning based on the study of the different geographical combinations, the relations between the villages, the communication ways, the ports and anchorages, and that some important places would already have been used in previous eras.
\end{abstract}

Keywords: Geography, Strategic Planning, Military Defence.

\section{La importancia estratégica del conocimiento del territorio en la formación de un sistema defensivo: el caso de Sintra (Portugal) durante la época islámica}

\section{Resumen}

El presente artículo busca entender, a partir del caso de Sintra durante el periodo islámico, cómo el conocimiento del territorio pesó en la estrategia de la construcción de fortificaciones y de las estructuras de vigilancia que permitian la defensa militar y formaban parte del sistema defensivo de la región de Lisboa. La metodología consiste en el intercambio de datos entre las fuentes arqueológicas, históricas, la toponimia y el reconocimiento geográfico. Los resultados muestran que Sintra, además de dos castillos y un ribat, ha tenido otras estructuras defensivas y puntos de control que permitian la comunicación con otros lugares de larga distancia y que marcaban el paisaje cultural marítimo. Las investigaciones muestran que la estructura de este sistema defensivo implicó una planificación estratégica basada en el estudio de las diferentes combinaciones geográficas, de las relaciones entre los pueblos, de las vías de comunicación, de los puertos y fondeaderos, y de algunos sitios importantes que habrían sido utilizados en épocas anteriores.

Palabras clave: geografía, planificación estratégica, defensa militar. 


\section{Introdução}

Durante a ocupação islâmica da Península Ibérica, e mais concretamente até 1147, ano da tomada da cidade de Lisboa aos mouros por D. Afonso Henriques e pelas forças cruzadas $^{1}$, Sintra fez parte do sistema de defesa militar do distrito (kura) de Lisboa (al-Ushbuna). A par de outras diversas localidades, e para além de integrar o território militarizado desse distrito, serviu de importante posto de alerta àquela cidade. De facto, a conjugação dos dados históricos, toponímicos e arqueológicos mostram que a cidade de Lisboa estava envolvida por um sistema de alerta e defesa costeira que incluiria, em particular, os seguintes locais: Sintra, Cascais e Oeiras², a Ocidente, Almada, Seixal e Palmela, a Sul, Montijo, a Oriente, Sacavém, Santa Iria de Azóia e Vila Franca de Xira, a Norte ${ }^{3}$.

Neste estudo desenvolveremos um pouco mais as investigações que temos vindo a realizar sobre a defesa costeira na área ocidental do distrito de Lisboa ${ }^{4}$, centrando as atenções na importância do conhecimento geográfico e na consequente apropriação e gestão do território para a formação de um sistema defensivo. Consequentemente, este tipo de trabalho obriga o investigador a fazer diversas deslocações e observações in loco, visando o reconhecimento geográfico do território e a assimilação da paisagem cultural marítima ${ }^{5}$, evitando assim possíveis abordagens simplistas ou desenquadradas quando se está a focar uma área que não se conhece ${ }^{6}$, que se revelou algo complexa do ponto de vista defensivo -abarcando outros locais num todo mais vasto- e que foi importante em larga diacronia ${ }^{7}$. Interessa não apenas procurar responder em que

\footnotetext{
${ }^{1}$ Sobre este assunto: Oliveira Borges, Marco. "Em torno da preparação do cerco de Lisboa (1147) e de uma possível estratégia marítima pensada por D. Afonso Henriques", em História. Revista da FLUP, vol. IV sér., núm. 3, Porto, Faculdade de Letras da Universidade do Porto, 2013, pp. 123-144.

${ }^{2}$ Para o caso de Oeiras: os dados e a bibliografia indicada por Oliveira Borges, Marco. "A defesa costeira no distrito de Lisboa durante o período islâmico. I-A área a ocidente da cidade de Lisboa ", em Tente, Catarina; et al. (coords.), Lisboa Medieval: Gentes, Espaços e Poderes. Textos seleccionados do III Colóquio Internacional "A Nova Lisboa Medieval» (Lisboa, FCSHNOVA, 20-22 de Novembro de 2013) (Lisboa: Instituto de Estudos Medievais) (no prelo).

${ }^{3}$ A súmula dos estudos indicados por Oliveira Borges, Marco. "A defesa costeira do litoral de SintraCascais durante a Época Islâmica. II-Em torno do porto de Cascais”, em Cunha, Ana; Pinto, Olímpia e Oliveira Martins, Raquel de (coords.), Paisagens e Poderes no Medievo Ibérico. Actas do I Encontro Ibérico de Jovens Investigadores em História Medieval. Arqueologia, História e Património, núm. 44 (Braga: Centro de Investigação Transdisciplinar «Cultura, Espaço e Memória»/Universidade do Minho, 2014), pp. 414-415.

${ }^{4}$ Recentemente, no âmbito do programa televisivo "Caminhos" (RTP2), tivemos a oportunidade de participar num episódio sobre "A defesa costeira no litoral de Sintra-Cascais durante o Período Islâmico", o qual pode ser visto através da seguinte ligação, https://www.youtube.com/watch?v=xVvG-KbkVvw\&t=12s (10 de Maio de 2015).

${ }^{5}$ Sobre esta noção: Ford, Ben. "Introduction", em Ford, Ben (ed.), The archaeology of maritime landscapes (New York: Springer, 2011), pp. 1-9. Para o caso de Sintra: Borges, Marco Oliveira. "Paisagem cultural marítima de Sintra: uma abordagem histórico-arqueológica”, em Actas do I Colóquio Ibérico de Paisagem. O estudo e a construção da Paisagem como problema metodológico (no prelo).

${ }^{6}$ Por exemplo: Christys, Ann. Vikings in the South. Voyages to Iberia and the Mediterranean (London/New York: Bloomsbury Academic, 2015), p. 76.

${ }^{7}$ Oliveira Borges, Marco. "A defesa costeira do litoral de Sintra-Cascais durante o Garb al-Ândalus. I-Em torno do porto de Colares”, em História. Revista da FLUP, vol. IV sér., núm. 2, Porto, Faculdade de Letras
} 
locais foram edificadas certas estruturas defensivas e de alerta, mas também tentar compreender a razão da sua localização e integração na lógica de um sistema de defesa militar, caminhando-se através de uma abordagem metodológica fortemente ligada ao conhecimento geográfico, fundamental neste e noutros tipos de estudos, mas nem sempre devidamente tido em conta. Note-se que a relação entre a História e a Geografia tem vindo a perder relevância, falando-se mesmo numa ausência de diálogo entre as duas disciplinas ${ }^{8}$.

Se na Antiguidade Pré-Clássica e Clássica o recurso à Geografia foi fundamental durante o planeamento de guerras, levando-se a cabo levantamentos geográficos e descrições de territórios que visavam conhecer melhor o espaço que se pretendia dominar ou defender ${ }^{9}$, assim continuou a ser com o decorrer dos séculos, acrescendo apenas a melhor precisão com que isso se foi fazendo face aos constantes avanços científicos e tecnológicos. Ao serviço do poder político e militar, o conhecimento geográfico serviu, antes de mais, para fazer a guerra ${ }^{10}$, sendo que vários autores, como foi o caso de Maquiavel, vieram a recuperar ideias do passado clássico ${ }^{11}$ e a conjugar com novas teorizações ${ }^{12}$. Com efeito, dentro deste pensamento impera a ideia de o homem, nomeadamente através desse poder político, recorrer ao conhecimento geográfico, a um saber estratégico para a elaboração de um plano militar-ofensivo ou

da Universidade do Porto, 2012; pp. 109-128; O porto de Cascais durante a Expansão Quatrocentista. Apoio à navegação e defesa costeira (dissertação de mestrado), UL, 2012, pp. 165-205; "Em torno da preparação do cerco de Lisboa (1147) e de uma possível estratégia marítima pensada por D. Afonso Henriques"..., pp. 126-140; "A defesa costeira do litoral de Sintra-Cascais durante a Época Islâmica. IIEm torno do porto de Cascais”, em Cunha, Ana, Pinto, Olímpia e Martins, Raquel de Oliveira (coord.), Paisagens e Poderes no Medievo Ibérico. Actas do I Encontro Ibérico de Jovens Investigadores em História Medieval. Arqueologia, História e Património..., pp. 409-435.

${ }^{8}$ Daveau, Suzanne. "História e Geografia: divórcio ou complementaridade?", em Seminário Internacional José Mattoso. Diálogos em torno da interdisciplinaridade: para uma outra visão da Idade Média, Universidade Nova de Lisboa, 20 de Novembro de 2014.

${ }^{9}$ Por exemplo, Montero, Santiago. El Emperador y los ríos. Religión, ingeniería y política en el Imperio Romano (Madrid: Universidad Nacional de Educácion a Distancia, 2012), pp. 36-37.

${ }^{10}$ Lacoste, Yves. A Geografia serve antes de mais para fazer a Guerra (Lisboa: Iniciativas Editoriais, 1977), pp. 8-16, embora não concordado totalmente quando se refere que este pensamento "não significa recordar as origens históricas do pensamento geográfico". Pode muito bem levar a isso.

11 Maquiavel, Nicolau. O Príncipe, introd. de Barreiros, José António, caps. III-V (Lisboa: Editorial Presença, 2008), caps. III-V, pp. 95-105 e passim.

${ }^{12}$ Note-se, a título de exemplo, a seguinte passagem: "Portanto, [o príncipe] nunca deve descurar o exercício da guerra, e deve exercitar-se mais em tempo de paz do que em tempo de guerra; o que pode fazer de duas maneiras: pelas obras ou em espírito. Quanto às obras, para além de manter os seus homens disciplinados e adestrados, deve dedicar-se à arte da caça, para habituar o corpo ao desconforto, e aprender a conhecer a natureza dos lugares, e a ver onde se erguem as montanhas, onde desembocam os vales, a extensão das planícies, e perceber a natureza dos rios e dos pântanos que existem, e estando sempre muito atento a tudo. Tal conhecimento é-lhe proveitoso de duas maneiras: primeiro, aprende a conhecer o seu país, e fica a conhecer melhor as suas defesas; segundo, graças ao conhecimento e à frequência desses lugares, pode compreender melhor qualquer outro lugar que necessite de explorar, já que os outeiros, os vales, as planícies, os rios e os pântanos que existem, por exemplo, na Toscana têm certa semelhança com os das outras regiões, de modo que pelo conhecimento da paisagem de uma província se pode facilmente conhecer as outras. O príncipe que não seja perito nesta matéria não possui a principal qualidade que um chefe militar deve possuir; porque é ela que o ensina a descobrir o inimigo, a escolher o melhor local para acantonar, a guiar os exércitos, a preparar as campanhas, a cercar com vantagem as cidades” Ibid., cap. XIV, p. 143. 
defensivo- que permitisse gerir o território que se pretendia conquistar ou continuar a manter em seu poder.

Para o caso de Sintra, é muito provável que já existissem algumas estruturas defensivas e de alerta antes da chegada dos muçulmanos. Ao ocuparem a Península Ibérica, a partir de 711, as forças muçulmanas tentaram "[...] dominar a totalidade dos seus territórios através da fixação de guarnições em cidades estratégicas e de pactos com antigos senhores hispano-visigodos", permitindo-lhes, “[...] mediante condições, continuar a controlar boa parte das suas antigas propriedades, ou mesmo manter parte do seu antigo poder"13. Em todo o caso, presume-se que apenas em 714 ou 716 Lisboa se tenha submetido pacificamente após um pacto de capitulação ${ }^{14}$, se bem que este seja um assunto que ainda não está devidamente compreendido ${ }^{15}$. Terá sido igualmente por esta altura que Sintra ficou sob poder muçulmano.

Certamente que com uma nova ocupação do território, e ao longo dos tempos, foram sendo repensadas formas de defesa terrestre e marítima, obedecendo a um planeamento estratégico. Ainda que o impulsionamento da defesa costeira islâmica seja atribuído à época que se seguiu aos primeiros ataques vikings, é preciso ter em conta que em 844, ano em que ficou registada a primeira investida destes guerreiros nórdicos às costas do Garb al-Ândalus, esta área "já era um cenário de guerra há mais de cem anos"16. Com efeito, isso leva a pensar que a paisagem já estaria marcada por fortificações cuja necessidade não foi criada pelas investidas nórdicas, mas apenas reforçada por elas ${ }^{17}$.

De qualquer forma, terá sido o desencadear das incursões vikings, chegando a alcançar o mar interior, que despoletou uma maior atenção defensiva por parte das autoridades muçulmanas, reforçando-se o aparelho militar e sistema de defesa costeira ao longo do litoral atlântico e mediterrânico. Sabe-se que o governo omíada reforçou a estrutura de defesa costeira e de vigilância com a edificação de torres de vigia (buruj, pl. de burj) e a utilização de sítios elevados e estratégicos que funcionavam como atalaias ${ }^{18}$ (tali' $a$, pl. de at-talai' a), bem como de diversas fortificações onde se incluíam castelos (husun, pl. de hisn) e conventos-fortificados (rubut, pl. de ribat ${ }^{19}$ ). Para além disso, tomaram-se medidas para a formação de uma marinha de guerra ampla e bem provida

\footnotetext{
${ }^{13}$ Barbosa, Pedro Gomes. Reconquista Cristã. Séculos IX-XII (Lisboa: Ésquilo, 2008), pp. 29-30.

${ }^{14}$ Oliveira Marques, A. H. de "O «Portugal» islâmico”, em Serrão, Joel e Oliveira Marques, A. H. de (Dir.), Nova História de Portugal, vol. II-Portugal das Invasões Germânicas à Reconquista (Lisboa: Editorial Presença, 1993), p. 122; Picard, Christophe. Le Portugal musulman (VIII-XIIIe siècle). L'Occident d'alAndalus sous domination islamique (Paris: Maisonneuve et Larose, 2000), pp. 22-23.

${ }^{15}$ Barbosa, Pedro Gomes, Op Cit., p. 31.

${ }^{16}$ Pires, Hélio. Incursões nórdicas no Ocidente Ibérico (844-1147): fontes, história e vestigios (tese de doutoramento), UNL, 2012, p. 243.

${ }^{17}$ Ibid.

${ }^{18}$ As atalaias podiam ser estruturas arquitectónicas (normalmente turriformes) ou simples locais destacados na paisagem de onde se exercia a vigilância e alertava para a chegada de inimigos (Barroca, Mário. “Atalaia”, em Alarcão, Jorge de e Barroca, Mário (coord.), Dicionário de Arqueologia Portuguesa (Porto: Figueirinhas, 2012), pp. 48-49.

${ }^{19}$ Sobre este termo, vide infra, núms. 50 e 51.
} 
de projécteis incendiários, tendo-se recrutado marinheiros e mercenários de várias partes, alguns deles especializados no lançamento de fogo-grego ${ }^{20}$.

Figura 1. Mapa simplificado do al-Ândalus e parte do Norte de África, c. 868.

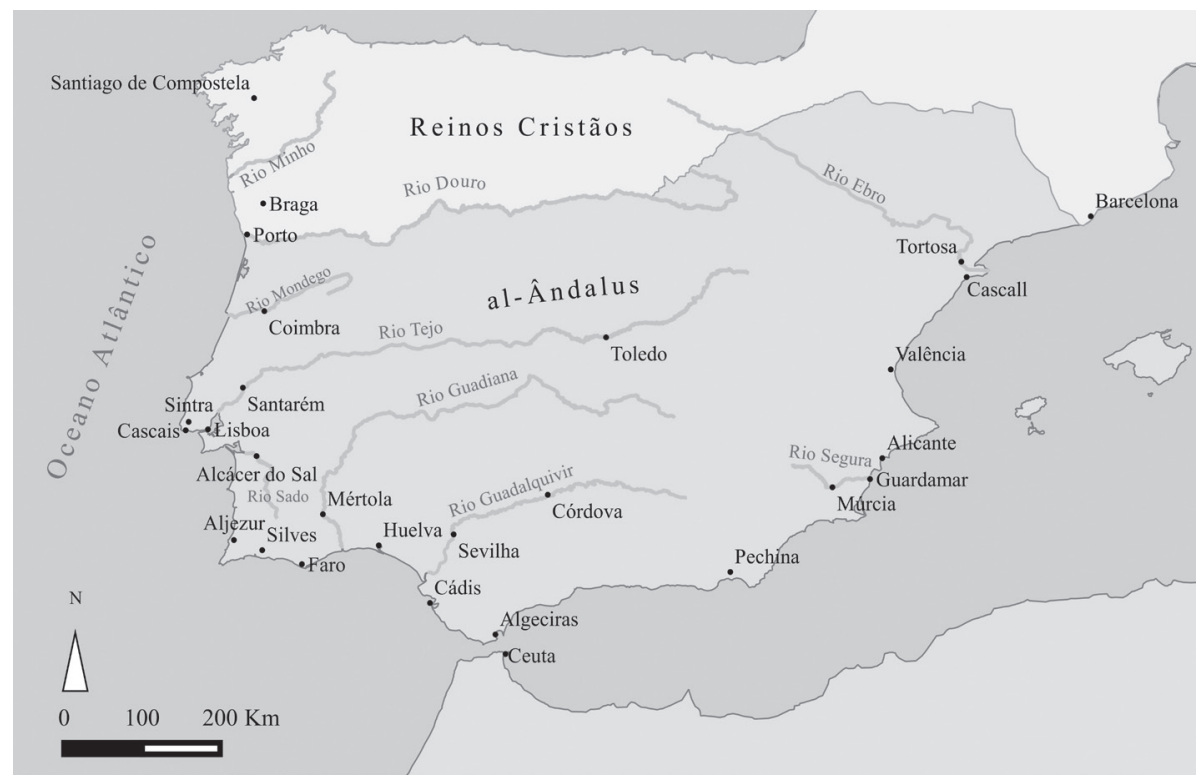

Fuente: Mapa feito para o autor por Luís Gonçalves.

\section{Os castelos de Sintra}

Situada a Noroeste de Lisboa, no extremo ocidental do al-Ândalus, junto ao mar tenebroso ${ }^{21}$, Sintra foi descrita por diversos autores muçulmanos. No século $\mathrm{X}$ seria já um importante centro populacional, embora não confinado ao castelo dos Mouros, quer pelas suas reduzidas dimensões e dificuldades de acesso, quer por estar afastado

\footnotetext{
${ }^{20}$ Sobre todas estas medidas: Abenalcotía. Historia de la conquista de España de Abenalcotía el Cordobés. Seguida de fragmentos históricos de Abencotaiba, etc., trad. de Ribera, Don Julián (Madrid: Tipografía de la Revista de Archivos, 1926), p. 53; Borges Coelho, António. Portugal na Espanha Árabe, 3. a ed. rev. (Lisboa: Editorial Caminho, 2008), pp. 169 e 173; Lirola Delgado, Jorge. El poder naval de al-Andalus en la época del califato omeya (siglo IV hégira/X era cristiana), (tesis doctoral), vol. I., UG, 1991, pp. 122-125; Picard, Christophe. La mer et les Musulmans d'occident au Moyen Age (VIIIe-XIIIe siècle) (Paris: Presses Universitaires de France, 1997), pp. 148 e 156; Catarino, Helena. "Breve sinopse sobre topónimos Arrábida na costa portuguesa”, em Franco Sánchez, Francisco (ed.), em La Rábita en el Islam. Estudios Interdisciplinares. Congressos Internacionals de Sant Carles de la Ràpita (1989, 1997) (Sant Carles de la Ràpita/Alacant: Ajuntament de Sant Carles de la Ràpita/Universitat d'Alacant, 2004), pp. 263267; Branco Correia, Fernando. "A acção do poder político nas actividades portuárias e na navegação no ocidente islâmico. Alguns tópicos”, em Solórzano Telechea, Jesús Angel e Viana, Mário (eds.), Economia e Instituições na Idade Média. Novas Abordagens (Ponta Delgada: Centro de Estudos Gaspar Frutuoso, 2013), pp. 14-38.
}

${ }^{21}$ Idrisi. Geografia de España (Valencia: Anubar, 1974), p. 74. 
das zonas agrícolas ${ }^{22}$. No século seguinte, al-Bakri (c. 1014-1094) colocou-a entre as doze cidades mais importantes do Garb al-Ândalus ${ }^{23}$.

Dotada de dois castelos de extrema solidez, um deles construído de forma estratégica num dos cumes sobranceiros da serra (castelo dos Mouros), Sintra foi mencionada posteriormente por al-Himyari -decerto baseado na obra de al-Bakri, embora esta tenha chegado aos nossos dias incompleta- como uma das vilas que dependiam de Lisboa no al-Ândalus, estando situada nas proximidades do mar e permanentemente mergulhada numa bruma que não se dissipava ${ }^{24}$.

Qual a época de construção destes dois castelos? No caso do castelo dos Mouros, tem sido referido que terão ocorrido duas fases distintas de edificação, sendo que a mais antiga remontará aos séculos IX-X, à semelhança de outros casos peninsulares, correspondendo à época de fortificação da costa atlântica levada a cabo pelas autoridades muçulmanas face aos ataques vikings ${ }^{25}$. No entanto, os trabalhos mais recentes têm apontado para cronologias de ocupação do local em torno dos séculos $\mathrm{X} \mathrm{e} \mathrm{XI}^{26}$.

Incorporado no sistema de defesa costeira que funcionava a partir do litoral sintrense, o castelo dos Mouros tinha a particularidade de servir como posto de vigia dos acessos por mar e terra e de, a partir daí, se poder estabelecer comunicação com outros postos defensivos a média e a longa distância. Porém, se é verdade que desse castelo e até mesmo de outros pontos elevados da serra de Sintra com grande ou maior visibilidade, e que articulariam funções entre si, era possível observar e estabelecer contactos com Mafra e outros locais mais a Norte ${ }^{27}$, com o porto de Cascais, Oeiras, outros sítios

${ }^{22}$ Coelho, Catarina. "O castelo dos Mouros (Sintra)", em Ferreira Fernandes, Isabel Cristina (coord.), Mil Anos de Fortificações na Península e no Magreb (500-1500). Actas do Simpósio Internacional sobre Castelos (Lisboa: Edições Colibri, 2002), p. 394.

${ }^{23}$ Al-Bakri, Abu Ubayd. Geografia de España (Kitab al-Masalik Wa-l-Mamalik), introd., trad, notas e índ, por Vidal Beltran, Eliseo (Zaragoza: Anubar, 1982), pp. 17-18; Rei, António. O Gharb al-Andalus al-Aqsâ na Geografia Árabe (séculos III h./IX d.C.-XI h./XVII d.C.) (Lisboa: Instituto de Estudos Medievais, 2012), pp. 124-125.

${ }^{24}$ Al-Himyari. Kitab ar-Rawd al-Mi tar, trad. por Maestro González, Ma Pilar (Valencia: Anubar, 1963), p. 233; Borges Coelho, António, Op Cit., p. 49; Rei, António, Op Cit., p. 166.

${ }^{25}$ Pavon Maldonado, Basilio. Ciudades y Fortalezas LusoMusulmanas. Crónicas de viajes por el sur de Portugal (Madrid: Instituto de Cooperación con el Mundo Árabe, 1993), pp. 20-25; Picard, Christophe e Ferreira Fernandes, Isabel Cristina. "La défense côtière à l'époque musulmane: l'exemple de la presqu'île de Setúbal", em Archéologie Islamique, núm. 8, Paris, 1999, pp. 74-75; Coelho, Catarina. "A ocupação islâmica do castelo dos Mouros (Sintra): interpretação comparada", em Revista Portuguesa de Arqueologia, vol. III, núm. 1, Lisboa, 2000, pp. 210-211, 214 e 218; Picard, Christophe. Le Portugal musulman..., pp. 209-210 e 215; Coelho, Catarina. "Castelo de Sintra: evidências arqueológicas do quotidiano entre os séculos IX-XII”, em Ferreira Fernandes, Isabel Cristina (coord.), Fortificações e Território na Península Ibérica e no Magreb (séculos VI a XVI), vol. II (Lisboa: Edições Colibri/Campo Arqueológico de Mértola, 2013), pp. 739-740.

${ }^{26}$ Sousa, Maria João de. "The castelo dos Mouros, Sintra", em Portugal. Report and proceedings of the 157th Summer Meeting of the Royal Archaeological Institute in 2011 (London: The Royal Archaeological Institute, 2012), p. 53.

${ }^{27}$ Chegou a ser referido que na área do castelo dos Mouros poderá ter existido uma torre de vigia romana 
da barra do Tejo, Lisboa e o seu castelo, Trafaria ${ }^{28}$, Almada, Palmela, Sesimbra e o cabo Espichel ${ }^{29}$, isso apenas seria possível em dias de boa visibilidade, o que nem sempre é realidade em Sintra, bastante sujeita aos nevoeiros que por ali se prolongam. De facto, integrado na vertente de vigilância e de alerta deste sistema defensivo, o castelo dos Mouros teria como principal função alertar os locais acima referidos sobre a aproximação de navios e de inimigos por terra, sendo de destacar Lisboa e os postos a Sul, mas nestas ocasiões de intenso nevoeiro, em que pouco ou nada se via quanto à linha de costa, não seria possível vislumbrar a aproximação de navios nem de produzir informação visual. Neste sentido, o sistema de alerta que funcionava através do castelo dos Mouros e de outros pontos da serra de Sintra estava bastante condicionado, tendo ficado inactivo com frequência ${ }^{30}$. No entanto, como alternativa e complemento, ao longo da linha costeira existiam outros postos de vigia e de retransmissão de sinais visuais, assunto que teremos oportunidade de focar mais adiante.

Qual o outro castelo de Sintra referido por al-Himyari? Em que local estaria situado? Quando foi construído? Quais as suas funções dentro deste sistema defensivo? Pese embora a hipótese comummente aceite de que um dos castelos de Sintra indicados por al-Himyari estaria edificado no sítio onde se encontra o actual Paço da vila, Maria Teresa Caetano referiu que o autor poderia querer reportar-se ao castelo de Colir (Colares) $^{31}$, o qual é apontado por João de Barros (1522). Curiosamente, este autor não hesita em considerar o castelo de Colir como sendo mais antigo do que o castelo de Sintra (Mouros) ${ }^{32}$. Contudo, o local onde terá sido erguido esse suposto castelo islâmico sofreu várias alterações ao longo dos séculos, pelo que até ao momento não foi possível confirmar vestígios da sua antiga existência. Durante o reinado de D. Manuel, e a partir da suposta estrutura islâmica, terá sido construída a Casa da Câmara de Colares, sendo que nas imediações foram detectados elementos pétreos de um

para observar o território em redor e o movimento marítimo, sendo possível observar dali as ilhas Berlengas, onde existiam assentamentos romanos. Ibíd.

${ }^{28}$ Sobre a comunicação visual entre Sintra e a Margem Sul do Tejo, os importantes dados aduzidos por Branco Correia, Fernando. "A acção do poder político as actividades portuárias e na navegação no ocidente islâmico. Alguns tópicos”, em Solórzano Telechea, Jesús Angel e Viana, Mário (eds.). Economia e Instituições na Idade Média. Novas Abordagens..., pp. 20-22; Branco Correia, Fernando. "Fortificações de iniciativa omíada no Gharb al-Andalus nos séculos IX e X-hipóteses em torno da chegada dos Majus (entre Tejo e Mondego)"..., pp. 77-79.

${ }^{29}$ Coelho, Catarina. "O Castelo dos Mouros (Sintra)"..., p. 3; Borges, Marco Oliveira. "A defesa costeira do litoral de Sintra-Cascais durante o Garb al-Ândalus. I-Em torno do porto de Colares”..., pp. 111-112; Oliveira Borges, Marco. O porto de Cascais..., pp. 175-176; Oliveira Borges, Marco. "Em torno da preparação do cerco de Lisboa (1147) e de uma possível estratégia marítima pensada por D. Afonso Henriques ”..., pp. 133-134; Correia, Fernando Branco. "A acção do poder político nas actividades portuárias e na navegação no ocidente islâmico. Alguns tópicos"..., pp. 20-22; Branco Correia, Fernando. "Fortificações de iniciativa omíada no Gharb al-Andalus nos séculos IX e X-hipóteses em torno da chegada dos Majus (entre Tejo e Mondego)"..., pp. 77-79.

${ }^{30}$ Oliveira Borges, Marco. "A defesa costeira do litoral de Sintra-Cascais durante o Garb al-Ândalus. I-Em torno do porto de Colares”..., pp. 111-112; Oliveira Borges, Marco. O porto de Cascais..., pp. 175-176. Sobre este assunto igualmente o vídeo citado na núm. 4.

${ }^{31}$ Caetano, Maria Teresa. Colares (Sintra: Câmara Municipal de Sintra, 2000), pp. 35-36, núm. 91.

${ }^{32}$ Barros, João de. Chronica do Emperador Clarimundo, Donde os Reis de Portugal Descendem, quinta impressão, t. III, cap. I, (Lisboa: Na Officina de João António da Silva, 1791), pp. 33 e 37-38. 
portal manuelino. Em inícios do século XVII, o edifício funcionava como Câmara e cadeia colarense, tendo sido adquirido por D. Dinis de Melo e Castro, antigo bispo de Leiria, Viseu e Guarda, que o transformou num palácio para sua habitação por volta de $1620^{33}$. O palácio terá ardido em meados do século XIX, tendo sido demolidas, já no início do século XX, as ruínas do Paço para a construção de uma escola primária ${ }^{34}$. No entanto, ainda hoje é possível observar uma arcada com terraço que restou desse palácio sobranceiro à vila moderna de Colares.

Situado numa área elevada, na vila velha colarense, desse suposto castelo muçulmano tinha-se uma visão privilegiada para o porto local e para o esteiro de mar que invadia o vale de Colares, controlando toda a área em redor e a serra, havendo ainda contacto visual excepcional com o castelo dos Mouros. Ao mesmo tempo, dessa primeira estrutura também se tinha visão singular para a área da actual praia das Maçãs -o acesso naval ao interior do território- e espaço marítimo envolvente, tendo o castelo "uma torre mui alta, que descobria o mar daí a dez léguas"35. Assim, do ponto de vista estratégico, faz todo o sentido que existisse um castelo precisamente na vila velha de Colares, onde alguns dados arqueológicos exumados confirmam a presença muçulmana pelo menos desde o século X. Escavações realizadas entre 1989-1990, junto à igreja Matriz de Colares, detectaram silos muçulmanos de onde foram obtidos abundantes fragmentos cerâmicos dos séculos $\mathrm{X}$ e $\mathrm{XI}^{36}$.

Embora por vezes a ideia da possível existência de um castelo muçulmano em Colares seja alvo de cepticismo, desvalorizando-se o que João de Barros escreve na Crónica do Imperador Clarimundo, é preciso ter em conta que as crónicas, por vezes, conservam reflexos de documentos e de obras perdidas no tempo, sendo "o único testemunho" para a "reconstituição de acontecimentos muito anteriores" à época em que são escritas ${ }^{37}$. Contudo, na impossibilidade de se confirmar a veracidade da tradição sobre este suposto castelo de origem muçulmana vinda de João de Barros e seguida por fr. Joseph de Santa Anna, somente a arqueologia poderá vir a trazer outras luzes sobre o assunto.

Enquanto se espera que um dia possam surgir novidades arqueológicas sobre a ocupação da vila velha de Colares durante o Período Islâmico, e até mesmo relacionadas com o próprio castelo, outros dados vão sendo explorados para se compreender melhor o povoamento local. É o caso de diversos topónimos sintrenses

\footnotetext{
${ }^{33}$ Pereira de Santanna, Frei Joseph. Chronica dos Carmelitas da Antiga, e Regular Observancia Nestes Reynos de Portugal, Algarves, e seus Domínios, t. II (Lisboa: Na Officina dos Herdeiros de António Pedrozo Galram, 1751), pp. 88-89.

${ }^{34}$ Caetano, Maria Teresa. Op. Cit., núms. 243 e 245, pp. 104-107.

${ }^{35}$ Barros, João de. Op. Cit., cap. I, pp. 19-20.

${ }^{36}$ Coelho, Catarina. “A ocupação islâmica do castelo dos Mouros (Sintra): interpretação comparada”..., p. 210; “O Castelo dos Mouros (Sintra)"..., p. 394.

${ }^{37}$ Mattoso, José. "Notas críticas às notas de fim de volume”, em Herculano, Alexandre, História de Portugal. Desde o começo da Monarquia até o fim do Reinado de Afonso III, vol. I (Amadora: Livraria Bertrand, 1980), p. 694; Oliveira-Leitão, André de. Povoamento no Baixo Vale do Tejo: entre a territorialização e a militarização (meados do século IX - início do século XIV) (dissertação mestrado), UL, 2011, p. 102.
} 
que, por exemplo, permitem aduzir mais informações e colocar hipóteses sobre a ocupação humana em torno do rio de Colares (fig. 2). Refira-se, deste modo, a própria origem do topónimo Colares, para a qual existem diferentes interpretações. A lenda da fundação do castelo de Colir diz que o actual topónimo Colares vem do nome dado a essa alegada fortificação por uma condessa vinda do Norte da Europa, que, fugindo ao rei da Dinamarca, aportou no rio local com duas naus, conseguindo autorização para permanecer e adquirir parte da terra ao rei mouro de Lisboa em troca do penhor de três colares de ouro ${ }^{38}$. Ao mandar edificar o castelo, a condessa, face ao penhor dos colares, deu-lhe o nome Colir, do qual teria derivado, mais tarde, Colares. Embora não tenha sustentado esta lenda, J. Diogo Correia admitiu que o topónimo poderá mesmo resultar "do simples aproveitamento do nome comum, colar, cujo étimo é o latim collare, de collum, pescoço, e que significa mesmo colar, coleira ou golilha" 39 . Numa outra interpretação, é referido que o topónimo Colares derivará do latim colle, estando associado a "colina", "outeiro", podendo, por outro lado, estar ligado a colo, de collum $^{40}$. Mais recentemente, Adalberto Alves relacionou o topónimo com o árabe kula, significando "pequeno lago" 41 .

Outro topónimo importante é Mucifal, que poderá derivar do árabe mussaffa, ou seja, "baixada", "vale inundado"42, dando assim sentido à ideia de que toda a área da várzea de Colares e arredores era inundada pelo mar e acessível à navegação. A aldeia do Mucifal fica muito próxima da vila velha de Colares, sendo um local em que foram encontradas ânforas Dressel 14 e_outros diversos vestígios romanos, os quais estariam associados a um antigo povoado ${ }^{43}$. Um outro topónimo das imediações do dito rio e que se pode relacionar com o passado islâmico, bem como com a defesa militar deste território, é Nafarros, estando situado um pouco a Noroeste do Mucifal. Recentemente, foi associado ao árabe nafar, significando "tropas" ou "exército"44. A Sul do referido curso de água temos Almoçageme, topónimo que poderá estar associado a uma antiga mesquita, al-mesjid ${ }^{45}$, sendo que ainda hoje subsiste na micro-toponímia de Colares

\footnotetext{
${ }^{38}$ Barros, João de. Op. Cit., cap. III, pp. 35-37.

${ }^{39}$ Correia, J. Diogo. "Toponímia estremenha”, em Estremadura. Boletim da Junta de Província, sér. II, núm. XLIV-XLVI, Lisboa, 1957, pp. 128-129.

${ }^{40}$ Ibid.; Caetano, Maria Teresa, Op. Cit., p. 9.

${ }^{41}$ Alves, Adalberto. "Mucifal", em Dicionário de Arabismos da Lingua Portuguesa (Lisboa: Imprensa Nacional-Casa da Moeda, 2013), p. 407.

${ }^{42}$ Ibid, p. 664.

${ }^{43}$ Coelho Pimenta, Frederico. "Subsídios para o estudo do material anfórico conservado no Museu Regional de Sintra”, em Sintria, vols. I-II, t. I, Sintra, Museu Regional de Sintra-Museu Arqueológico de São Miguel de Odrinhas, 1982-1983, pp. 135-138 e 145-147; Oliveira Borges, Marco. "Portos e ancoradouros do litoral de Sintra-Cascais. Da Antiguidade à Idade Moderna (I)", em Actas das Jornadas do Mar 2014. Mar: Uma onda de Progresso (Almada: Escola Naval, 2015), pp. 154-155; Oliveira Borges, Marco. "Navegação comercial fluvio-marítima e povoamento no Ocidente do Municipium Olisiponense: em torno dos rios Lizandro (Mafra) e Colares (Sintra)”, em Estudos em História da Antiguidade Clássica (no prelo).

${ }^{44}$ Alves, Adalberto. "Nafarros" em Op. Cit., p. 673.

${ }^{45}$ Guedes Real, Mário “Toponímia árabe da Estremadura”, em Estremadura. Boletim da Junta de Província, sér. II, núm. 10, Lisboa, 1945, p. 301; Carvalho, Sérgio Luís de. "A presença árabe em Sintra durante a Idade Média”, em História, núm. 101, 1987, p. 90.
} 
a Rua da Mesquita ${ }^{46}$. A existência de mesquitas é bastante importante no contexto militar que temos vindo a referir, pois eram locais onde também se podiam agrupar os monges guerreiros e outros homens que se dedicavam ao exercício da espiritualidade e ao combate contra o inimigo.

Figura 2. Povoamento nas proximidades do rio de Colares segundo a Carta chorographica dos terrenos em volta de Lisboa comprehendendo a principal parte do Tejo adjacente à sua foz, escala $1 / 100.000$.

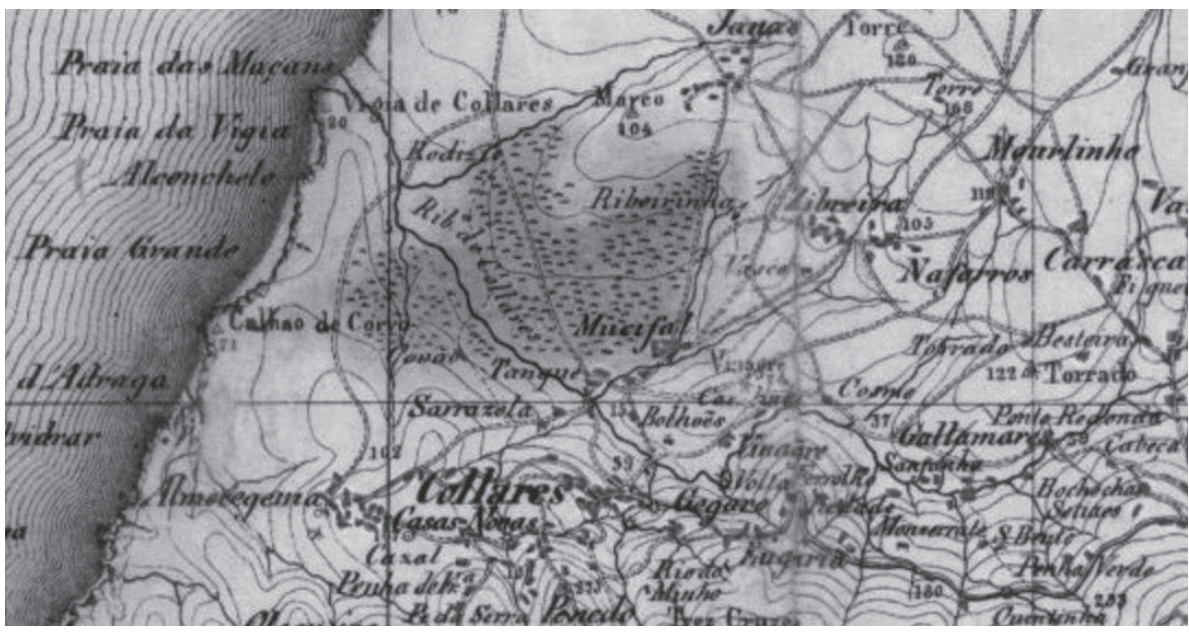

Fuente: Lisboa: Direcção dos Trabalhos Geodésicos do Reino, 1856-1866.

\section{$\mathrm{O}$ ribat do Alto da Vigia}

O Alto da Vigia é um pequeno outeiro que fica situado junto à praia das Maçãs, na margem esquerda da desembocadura do rio de Colares, curso de água que nasce a c. $14 \mathrm{~km}$ da sua foz, estando actualmente reduzido à condição de ribeira. Em épocas passadas um esteiro de mar invadia esta área, permitindo a navegabilidade do vale de Colares, o acesso naval ao interior do território e ao porto local ${ }^{47}$.

Em 2008, durante intervenções arqueológicas realizadas no Alto da Vigia que visavam averiguar a existência do santuário romano consagrado ao Sol e à Lua que se sabia ter existido no litoral de Sintra, foram detectados importantes vestígios de diferentes cronologias, inicialmente associados a uma vigia ${ }^{48}$, porquanto parte da sua estrutura

\footnotetext{
${ }^{46}$ Oliveira Borges, Marco. "O sistema defensivo de Sintra durante o Período islâmico", em Congresso Internacional O Mediterrâneo e o Sul Ibérico na Época Medieval. Cultura, Identidade e Património, Universidade de Évora, 23 de Maio de 2014.

${ }^{47}$ Oliveira Borges, Marco. "A defesa costeira do litoral de Sintra-Cascais durante o Garb al-Ândalus. I-Em torno do porto de Colares"..., pp. 116-128; "Portos e ancoradouros do litoral de Sintra-Cascais. Da Antiguidade à Idade Moderna (I)"..., pp. 152-160; "Navegação comercial fluvio-marítima e povoamento no Ocidente do Municipium Olisiponense: em torno dos rios Lizandro (Mafra) e Colares (Sintra)"...

${ }^{48}$ Até recentemente foi interpretada pelos arqueólogos como sendo a torre de um facho (Jordão, Patrícia, Mendes, Pedro e Gonçalves, Alexandre. Alto da Vigia (Colares, Sintra). Relatório dos Trabalhos Arqueológicos [de 2008], 2009, p. 3 [policopiado]; Gonçalves, Alexandre Marques. Alto da Vigia (Colares,
} 
ainda estava visível à superfície. $\mathrm{O}$ decorrer dos trabalhos permitiu confirmar que foi neste local que os romanos construíram o dito santuário, mas a grande surpresa esteve na detecção parcial das estruturas de um edifício islâmico que tem vindo a ser referido com sendo um ribat ${ }^{49}$. Assim, na actualidade, o Alto da Vigia representa o sítio arqueológico romano e islâmico mais ocidental do continente europeu.

O termo ribat, para além de arquitectonicamente designar uma estrutura fortificada (ou não), contém um significado ligado ao exercer da espiritualidade própria da guerra religiosa ${ }^{50}$. Assim, este termo pode ser aplicado a um assentamento militar em que se faz o ribat espiritual, em que existe uma actividade bélica importante e com população variada $^{51}$, mas também a uma determinada área geográfica onde decorriam essas acções. Em todo o caso, não é consensual a discussão em torno das funções dos rubut, havendo investigadores que diminuem a importância militar e defensiva que costuma ser atribuída a estes edifícios, favorecendo mais os aspectos religiosos, estando os ocupantes destas estruturas mais ligados a práticas ascéticas embora não descurando as tarefas de vigilância e de sinalização do perigo inimigo. Por outro lado, em certas áreas, os rubut também estiveram ligados a actividades comerciais marítimas, pelo que poderá ter acontecido o mesmo em Sintra. Partindo da ideia de que nem todas estas estruturas terão sido erguidas exactamente com a mesma tipologia construtiva e o mesmo propósito específico, embora tenham acumulado funções associadas à prática de ribat e, ao longo da sua existência, até possam ter ganho outras utilidades diferentes das que inicialmente teriam presidido à sua edificação -isto mediante uma adaptação a diferentes conjunturas históricas-, a exploração da realidade geográfica e do contexto histórico em que se inseriam é fundamental para se tentar compreender o seu antigo funcionamento e as razões da sua implantação em determinado local.

Num contexto militar e estrutural, o ribat costuma ser designado como sendo um convento, um convento-fortificado ou mosteiro-fortaleza associado à protecção dos espaços de fronteira terrestre e marítima, estando igualmente ligado às lides da defesa costeira. Era um dos edifícios onde os monges guerreiros, outros combatentes e voluntários preparavam a jihad contra os cristãos ${ }^{52}$, contra os vikings e até mesmo contra os inimigos internos. No caso da Península Ibérica, a primeira descoberta de um ribat ocorreu nas dunas de Guardamar (Alicante), junto à desembocadura do antigo delta do rio Segura (1984), sendo que os dados arqueológicos obtidos apontam para uma cronologia de ocupação do local desde finais do século IX ${ }^{53}$. A segunda detecção

Sintra). Relatório dos trabalhos arqueológicos de 2013, 2014, pp. 11-12 [policopiado])

${ }^{49}$ Gonçalves, Alexandre Marques. Escavação arqueológica do Alto da Vigia (Colares-Sintra): relatório da intervenção realizada em 2015, 2016, pp. 7-9, 67 e 70-75 [policopiado].

${ }^{50}$ Epalza, Míkel de. "La Ràpita Islámica: Historia Institucional”..., pp. 6-7 e 27.

${ }^{51}$ Ibid., p. 27.

${ }^{52} \mathrm{O}$ geógrafo Al-Bakri referiu que o al-Ândalus era um território de jihad, estando rodeado por infiéis de diversas origens. Al-Bakri, Abu Ubayd, Op Cit., p. 39.

${ }^{53}$ Azuar, R. "El ribât en al-Andalus: espacio y función”, em Ilu. Revista de Ciencias de las Religiones. Anejos, vol. X, Madrid, 2004, pp. 27-28; Azuar. "O contributo da Arqueologia para o estudo dos ribat-s do Al-Andalus", em Ribat da Arrifana. Cultura material e espiritualidade (Aljezur: Associação de Defesa do Património Histórico e Arqueológico de Aljezur, 2007), pp. 30-32. 
viria a ser feita na Arrifana (Aljezur), mais concretamente numa pequena península denominada Ponta da Atalaia (2001), sendo que o ribat em questão tem sido associado a ordens de construção de Ibn Qasi, por volta de $1130^{54}$. No entanto, existe uma linha de pensamento_divergente e que coloca a sua edificação numa época anterior, não estando relacionada com aquele mestre sufi, até porque o edifício mandado levantar por este teria sido construído noutro local ${ }^{55}$. Por fim, a terceira descoberta, com o consequente desenvolvimento de intervenções arqueológicas, tem vindo a ser indicada para o Alto da Vigia (Sintra) ${ }^{56}$, não parecendo haver outro registo positivo a nível peninsular até ao presente ${ }^{57}$. Em todo o caso, e olhando apenas para o actual território português, a dispersão destas estruturas terá abrangido uma área bastante vasta, tendo existido na área do rio Douro (muito provavelmente já em 876-877), na área fluvial da Grande Lisboa (pelo menos em Sacavém), na Península de Setúbal, na costa algarvia e noutros possíveis locais em que perdurou o topónimo Arrábida ${ }^{58}$.

As escavações no Alto da Vigia ainda estão numa fase embrionária ${ }^{59}$. Até à campanha arqueológica de 2015 conheciam-se três salas que integravam o ribat, uma delas com um mihrab virtualmente orientado para Meca, e outros vestígios contemporâneos da ocupação islâmica, nomeadamente pisos de terra batida, silos e sepulturas, sendo que nem todos estão escavados na sua totalidade ${ }^{60}$. De acordo com Alexandre Gonçalves, a nível da planta e das técnicas de construção, o ribat do Alto da Vigia parece apresentar características semelhantes aos que foram identificados em Guardamar e na Arrifana, enquadrando-se numa possível tipologia construtiva presente no al-Ândalus ${ }^{61}$. Porém, somente o decorrer dos trabalhos poderá confirmar essa hipótese ${ }^{62}$. Naturalmente que a dimensão estrutural do edifício de Sintra ocupará uma área mais alargada do que

\footnotetext{
${ }^{54}$ Varela Gomes, Rosa e Varela Gomes, Mário. "O Ribat da Arrifana (Aljezur, Algarve): resultados da campanha de escavações arqueológicas de 2002", em Revista Portuguesa de Arqueologia, vol. VII, núm. 1, Lisboa, 2004, pp. 483 e 560; Varela Gomes, Mário. "Ibn Qasi-Vida e obra do mestre sufi da Arrifana”..., p. 41.

${ }^{55}$ Macias, Santiago. "Resenha dos factos políticos", em Mattoso, José (Dir.), História de Portugal, vol. I-Antes de Portugal ([s.1.]: Editorial Estampa, 1997), p. 380; Cavaco, Sandra. O arrabalde da Bela Fria. Contributos para o estudo da Tavira islâmica, (dissertação de mestrado), UA, 2011, pp. 57-59; Macias, Santiago. "Archéologi islamique au Portugal: bilan et thèmes de recherche", em Sénac, Philippe (ed.), Histoire et archéologi de l'Occident musulman (VIIe-XVe siècles). Al-Andalus, Maghreb et Sicile (Toulouse: CNRS-Université de Toulouse-Le Mirail, 2012), p. 109; Carvalho, António Rafael e Wu, Chia-Chin. "A influência do oceano Atlântico/Bahr Uqiyanus al-A'zam na procura de Deus/Allah: uma reflexão, desde o Alentejo litoral/sahil de al-Qasr, até à costa vicentina/sahil de Silves" (no prelo).

${ }^{56}$ Marques Gonçalves, Alexandre. Escavação arqueológica do Alto da Vigia (Colares-Sintra)..., pp. 8-9.

${ }^{57}$ Contudo, na área da praia dos Coelhos (Galápos, Setúbal), em pleno litoral da serra da Arrábida, foram identificados vestígios arqueológicos que chegaram a levar à hipótese de se estar perante um local onde existiu um ribat ou apenas uma rábita. Carvalho, António Rafael e Sousa, Vítor Rafael de. "A presença tardoromana e muçulmana na praia dos Coelhos. Notícia preliminar”, em Al-Madan, vol. II sér., núm. 12, Almada, 2003, 187-188; Carvalho, António Rafael e Wu, Chia-Chin, Op Cit.).

${ }^{58}$ A bibliografia indicada por Oliveira Borges, Marco. "A defesa costeira no distrito de Lisboa durante o período islâmico. I-A área a ocidente da cidade de Lisboa”...

${ }^{59}$ Marques Gonçalves, Alexandre, Op Cit., p. 9.

${ }^{60}$ Ibid., pp. 14-15, 37, 46-48, 62 e 70.

${ }^{61}$ Azuar, R. "El ribât en al-Andalus: espacio y función"..., p. 23; "O contributo da Arqueologia para o estudo dos ribat-s do Al-Andalus"..., pp. 29 e 35-36; Varela Gomes, Rosa e Varela Gomes, Mário. “Ambiente natural e complexo edificado"..., pp. 63-64; Marques Gonçalves, Alexandre, Op Cit., p. 9.

${ }^{62}$ Ibid
} 
aquela que está a ser alvo de escavações, sendo que as prospecções geofísicas levadas a cabo revelaram a existência de outras estruturas por escavar ${ }^{63}$. Neste sentido, está ainda por perceber a real extensão do sítio arqueológico, esperando-se que em breve surjam novos dados que permitam compreender melhor a ocupação do local e aclarar as várias dúvidas que persistem ${ }^{64}$. De qualquer forma, para já pode-se dizer que a estrutura que está a ser intervencionada não tem o aspecto de um verdadeiro recinto fortificado como se pode ver nos rubut do Norte de África-caso de Tunes ${ }^{65}$.

Um dos aspectos mais importantes a destacar tem a ver com as várias fases de ocupação islâmica que têm vindo a ser detectadas e que vieram sucessivamente a alterar o sítio $^{66}$. Outro pormenor que interessa salientar é que as campanhas de escavação têm mostrado que a edificação das estruturas islâmicas foi feita com múltiplos elementos arquitectónicos e epigráficos do templo romano precedente ${ }^{67}$. Para além disso, refira-se que as estruturas do ribat detectadas encontram-se bastante destruídas, sendo que isso também se deverá à remoção e reutilização das suas pedras na edificação da vigia ali identificada, a qual tem sido associada ao reinado de D. Manuel I ${ }^{68}$.

Ainda que as estruturas islâmicas que têm vindo a ser escavadas no Alto da Vigia não apresentem a tipologia arquitectónica de outros rubut já identificados fora do alÂndalus, não se pode deixar de associar este ribat sintrense à defesa costeira. Assim, contrariamente a interpretações que ligam a edificação desta estrutura essencialmente a questões espirituais e religiosas, a existência de um ribat ou de outros edifícios com função de ribat naquele outeiro junto à foz do rio de Colares -por onde entrava um braço de mar-, revela claramente uma necessidade estratégica de ter um local abrigado em que se pudessem agrupar homens capazes de proteger um espaço que era comum à navegação e que, no fundo, permitia o acesso naval ao interior do território ${ }^{69}$ e ao porto local (c. $4 \mathrm{~km}$ a montante) $)^{70}$.

De facto, sabe-se que estas estruturas eram construídas em áreas marítimas importantes, algumas mesmo na desembocadura de rios para protegeram o acesso a portos interiores,

\footnotetext{
${ }^{63}$ É de salientar que parte do sítio arqueológico, na área extrema Poente, foi desaparecendo com o desabe de parte do Outeiro devido à acção dos agentes erosivos e de acidentes naturais que ocorreram ao longo dos séculos (fig. 5).

${ }^{64}$ Carvalho, António Rafael e Wu, Chia-Chin, Op Cit., inclinam-se para a ideia de que a estrutura que está a ser escavada não seja um ribat, mas sim uma "zawiya, como sinónimo de rabita", tratando-se assim de uma pequena mesquita isolada já da época almorávida. No entanto, contrariamente a esta perspectiva, a mesquita até agora identificada será apenas uma de outras que farão parte do ribat.

${ }^{65}$ Marques Gonçalves, Alexandre, Op Cit, p. 9.

${ }^{66}$ Ibid., pp. 70-75.

${ }^{67}$ Ibid., pp. 67 e 89.

${ }^{68}$ Ibid., pp. 10, 35-36 e 91; Ribeiro, José Cardim. “Ad Antiquitates Vestigandas. Destinos e itinerários antiquaristas nos campos olisiponenses ocidentais desde inícios a meados do século XVI", em González Germain, Gerard (coord.), Peregrinationes ad inscriptiones colligendas. Estudios sobre epigrafia de tradición manuscrita (Bellaterra: Universitat Autònoma de Barcelona, 2016), p. 140.

${ }^{69}$ Oliveira Borges, Marco. "A defesa costeira do litoral de Sintra-Cascais durante o Garb al-Ândalus. I-Em torno do porto de Colares"..., pp. 119-120; O porto de Cascais..., pp. 167-168, núm. 632 e 180; "Portos e ancoradouros do litoral de Sintra-Cascais. Da Antiguidade à Idade Moderna (I)"..., p. 158; "Navegação comercial fluvio-marítima e povoamento no Ocidente do Municipium Olisiponense: em torno dos rios Lizandro (Mafra) e Colares (Sintra)"...

${ }^{70}$ Oliveira Borges, Marco. O porto de Cascais..., p. 38.
} 
embora para os casos do Norte de África e do Mediterrâneo oriental seja apontada uma finalidade mais ligada ao movimento comercial marítimo do que propriamente aos aspectos militares ${ }^{71}$. Em todo o caso, para o litoral catalão, por exemplo, al-Idrisi (1099-1165/66) refere uma "rabita de Kashtali", situada a Sul de Tortosa, como sendo "formosa, forta i inexpugnable vora la mar i compta amb una guarnició (qawm) brava"

Reforçando a ideia de que o principal motivo da implantação de um ribat naquela área sensível da costa de Sintra tenha sido por aspectos defensivos, a utilização militar daquele outeiro onde se encontram as ruínas da estrutura islâmica levanta diversas questões, sendo que a leitura geo-estratégica do local permite colocar a hipótese de terem existido outras estruturas mais para Sul e, sobretudo, para Norte, na área mais próxima e fronteira à actual foz da ribeira de Colares $^{73}$. Era este o local por onde entrava o esteiro de mar e em que se fazia a interdição da entrada de navios para o interior do território $^{74}$. Por conseguinte, a defesa da entrada do antigo esteiro navegável seria feita, em primeira instância, pelas forças destacadas no local. Mas para além dos ocupantes do edifício e de outras possíveis estruturas próximas desse sítio estarem envolvidos nessa defesa, daquela área era possível estabelecer contacto visual e comunicar com os postos defensivos dos arredores, com outros situados mais para o interior e até com o castelo dos Mouros, pelo que em sinal de alarme outros guerreiros e monges voluntários das redondezas acorreriam ao local em auxilio dos que lá estavam fixos.

No que respeita à cronologia de fundação deste ribat, e ainda que tenha sido ocupado durante várias fases do Período Islâmico ${ }^{75}$, ainda não é possível avançar com um momento exacto. No entanto, as cerâmicas exumadas até 2015, e que permitem estabelecer alguns paralelos com materiais recolhidos em Lisboa, no ribat da Arrifana e no Algarve, enquadram-se em contextos cronológicos que se estendem entre o período emiral e o século XII ${ }^{76}$. Conquanto ainda se esteja numa fase embrionária de análise, é possível que este ribat tenha sido edificado no âmbito do reforço do sistema defensivo do litoral atlântico e mediterrânico face aos primeiros ataques nórdicos, podendo remontar a um período muito próximo de 844 , de modo a impedir o acesso viking ao interior de Sintra ${ }^{77}$.

\footnotetext{
${ }_{71}$ Algumas rotas comerciais da costa oriental mediterrânica e do Norte de África eram apoiadas em rubut, com navios a chegarem das costas cristãs carregados de produtos, sendo que o aviso da sua chegada era dado através das torres de vigia com as gentes da região a acorrerem aos rubut para comerciarem. Azuar, R. "El ribât en al-Andalus: espacio y función”..., pp. 28-29; "O contributo da Arqueologia para o estudo dos ribat-s do Al-Andalus"..., p. 32).

${ }^{72}$ Apud Bramon, Dolors. "La Ràpita del Cascall al delta de l'Ebre”..., p. 120.

${ }^{73}$ A posição estratégica do Alto da Vigia e a possível extensão mais alargada da área ocupada pelas estruturas islâmicas têm sido prontamente reconhecidas por alguns investigadores que têm visitado o local, caso de Branco Correia, Fernando. "A acção do poder político nas actividades portuárias e na navegação no ocidente islâmico. Alguns tópicos”..., p. 20; "Fortificações de iniciativa omíada no Gharb al-Andalus nos séculos IX e X-hipóteses em torno da chegada dos Majus (entre Tejo e Mondego)”..., p. 77.

${ }^{74}$ Oliveira Borges, Marco. "A defesa costeira do litoral de Sintra-Cascais durante o Garb al-Ândalus. I-Em torno do porto de Colares”..., pp. 119-120; O porto de Cascais ..., pp. 167-168, n. 632 e 180.

${ }^{75}$ Marques Gonçalves, Alexandre, Op Cit, pp. 70-75..

${ }^{76}$ Ibid., pp. 77-85.

${ }^{77}$ Oliveira Borges, Marco. "A defesa costeira do litoral de Sintra-Cascais durante o Garb al-Ândalus. I-Em torno do porto de Colares”..., pp. 119-120 e 125, núm. 89; O porto de Cascais..., pp. 167-168, núm. 632 e 180.
} 
As fontes históricas conhecidas nada dizem sobre a estrutura do Alto da Vigia, pelo que as iniciativas de construção tanto poderão ter partido do poder central (Córdova) como das dinastias rebeldes regionais. Note-se que, embora logo após os ataques nórdicos de 844 o poder central tenha ordenado o reforço da defesa marítima ao longo da costa atlântica e mediterrânica, a verdade é que arquitectura militar do Garb al-Ândalus também foi dirigida por rebeldes e dinastias regionais ${ }^{78}$. Mas o facto de os dados obtidos nas escavações de Sintra mostrarem que o local teve várias fases de ocupação islâmica, mantendo-se muito provavelmente até à época da tomada de Lisboa, ajuda a perceber que por ali terão passado não apenas homens locais mas também possivelmente forças enviadas pelo poder central ou até voluntários vindos de locais distantes. Sabe-se que, para além da mão-de-obra local e das forças enviadas por Córdova para diversos pontos do al-Ândalus, também vinham voluntários de outras partes a favor da jihad, devendo essas deslocações ter propiciado igualmente a ocupação de locais costeiros estratégicos que se revelavam mais sensíveis à chegada inimiga ${ }^{79}$.

Como exemplo da importância e necessidade de se proteger o acesso naval ao interior de Sintra, e no âmbito do que temos vindo a mostrar, importa referir o caso do ataque de Sigurd àquela povoação. Terá sido pelo esteiro de Colares que Sigurd, jovem comonarca norueguês, lançou um ataque a Sintra em $1109^{80}$, podendo não ter sido a primeira vez que forças nórdicas subiram aquele braço de mar.

Figura 3. Pormenor da área de Colares. Carta Militar de Portugal, Colares (Sintra), escala $1 / 25.000$, folha 415 .

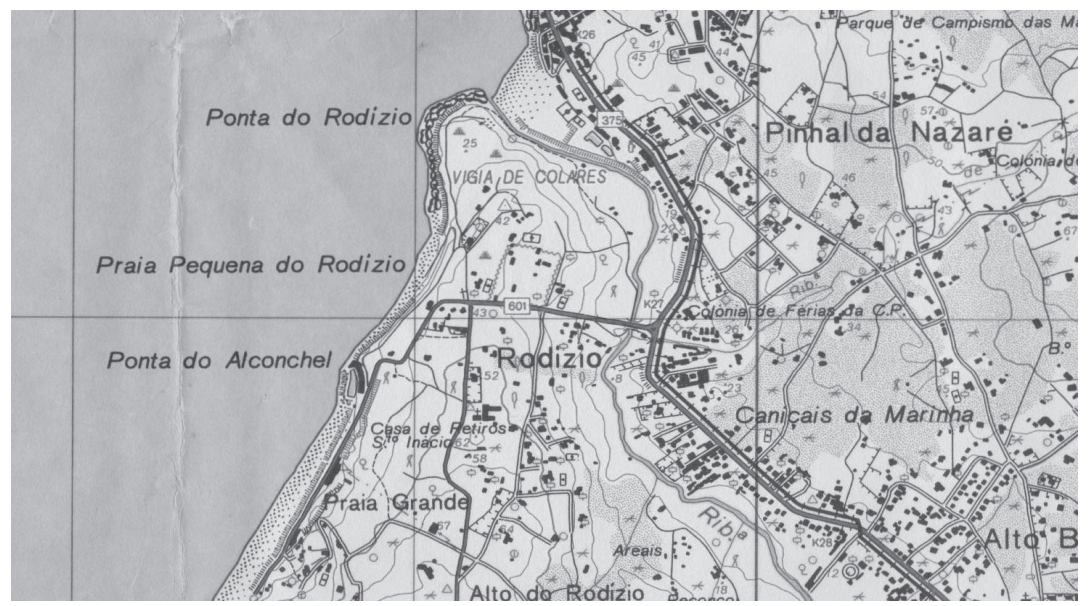

Fuente: Serviço Cartográfico do Exército, 1991.

\footnotetext{
${ }^{78}$ Branco Correia, Fernando. "Fortificações de iniciativa omíada no Gharb al-Andalus nos séculos IX e X-hipóteses em torno da chegada dos Majus (entre Tejo e Mondego)”..., pp. 74-75.

${ }^{79}$ Branco Correia, Fernando. "A acção do poder político nas actividades portuárias e na navegação no ocidente islâmico. Alguns tópicos"..., pp. 15, 21 e 24; "Fortificações de iniciativa omíada no Gharb al-Andalus nos séculos IX e X-hipóteses em torno da chegada dos Majus (entre Tejo e Mondego)”..., p. 75.

${ }^{80}$ Caetano, Maria Teresa, Op Cit., p. 41; Oliveira Borges, Marco. "A defesa costeira do litoral de SintraCascais durante o Garb al-Ândalus. I-Em torno do porto de Colares”..., pp. 124-125; O porto de Cascais..., pp. 167-168; "Portos e ancoradouros do litoral de Sintra-Cascais. Da Antiguidade à Idade Moderna (I)"..., p. 160; Pires, Hélio. "Word from the South: a source for Morkinskinna?", em Viking and Medieval Scandinavia, núm. 10, Turnhout, 2014, p. 183.
} 
Figura 4. Vista do Alto da Vigia para a praia das Maçãs (Dezembro de 2011).

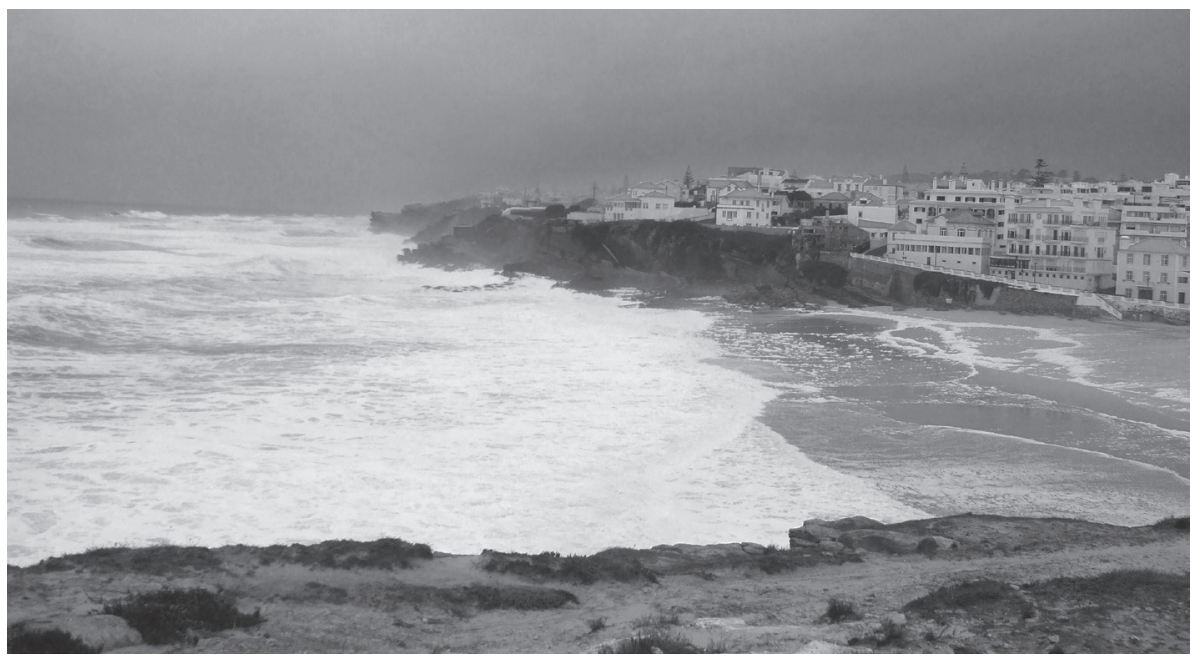

Fuente: Foto do autor.

Figura 5. Alto da Vigia. Perspectiva aérea do local onde se realizam os trabalhos arqueológicos (Abril de 2015).

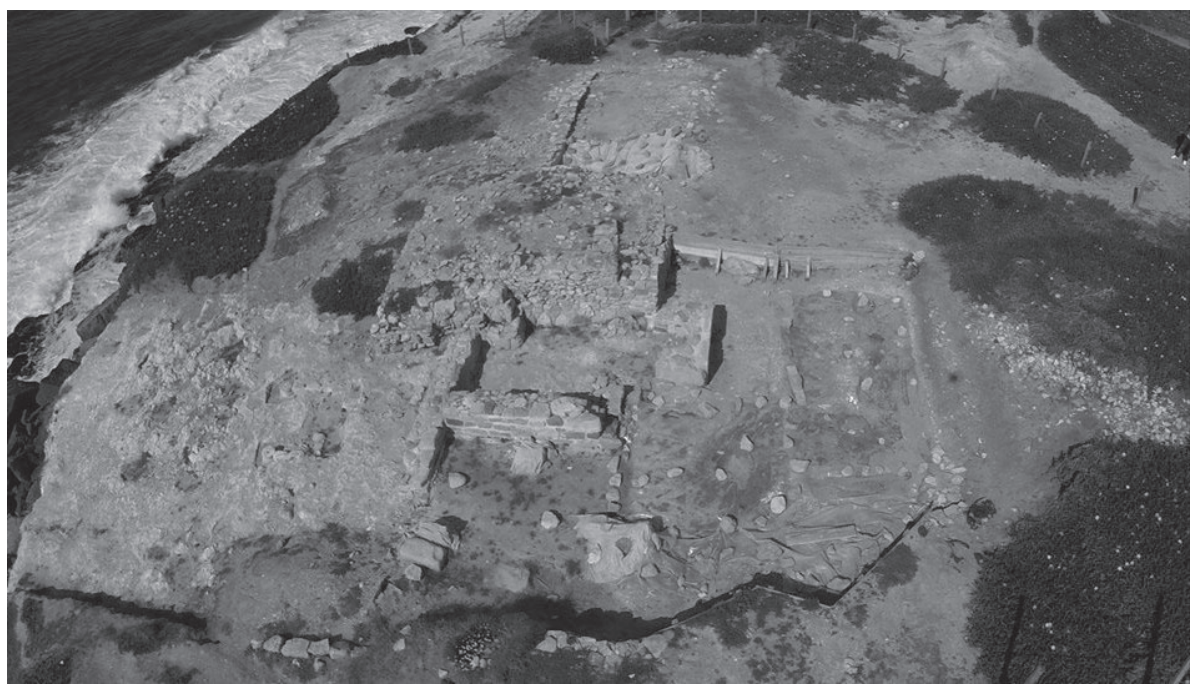

Fuente: Imagem aérea captada em Abril de 2015. Cedida ao autor por Ana de Frias. 
A importância estratégica do conhecimento do território na formação de um sistema...

Figura 6. Pormenor de uma das salas do ribat do Alto da Vigia. Destaque para o mihrab, virtualmente orientado no sentido de Meca.

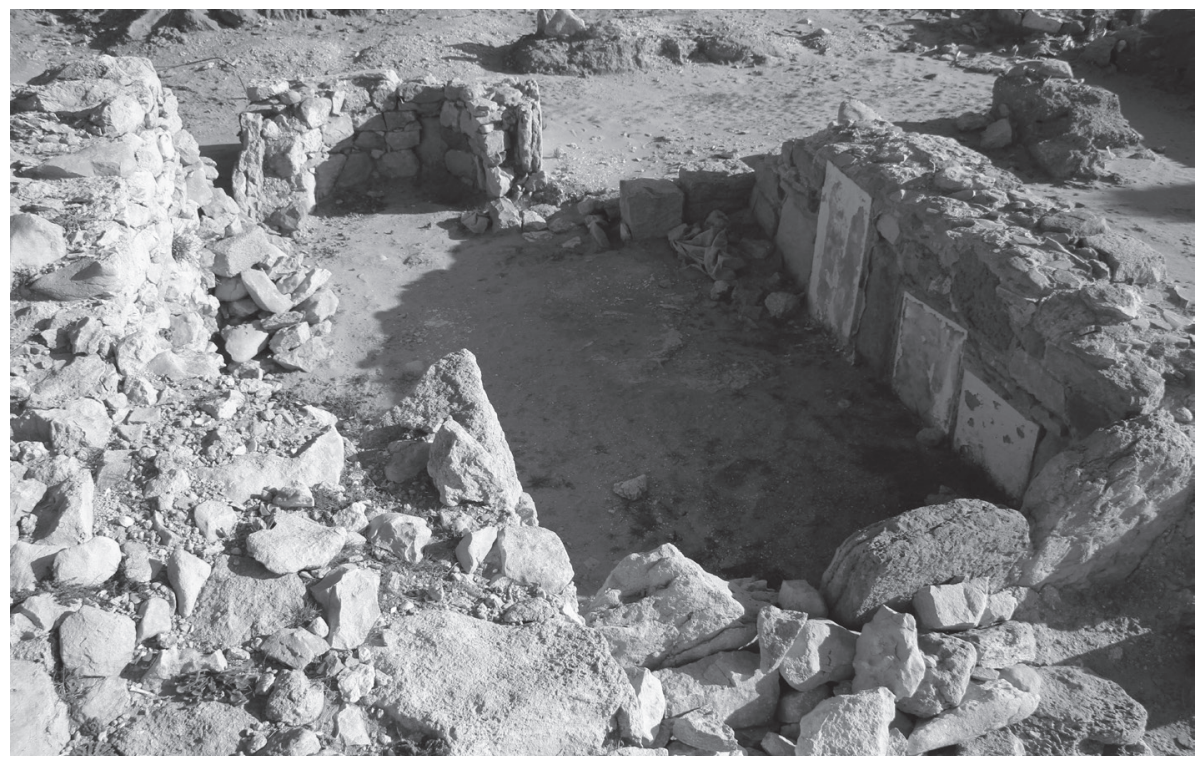

Fuente: Raul Losada/Portugal Romano. Cedida ao Autor por Raul Losada.

Figura 7. Uma outra sala do ribat vista para Sul (Setembro de 2016).

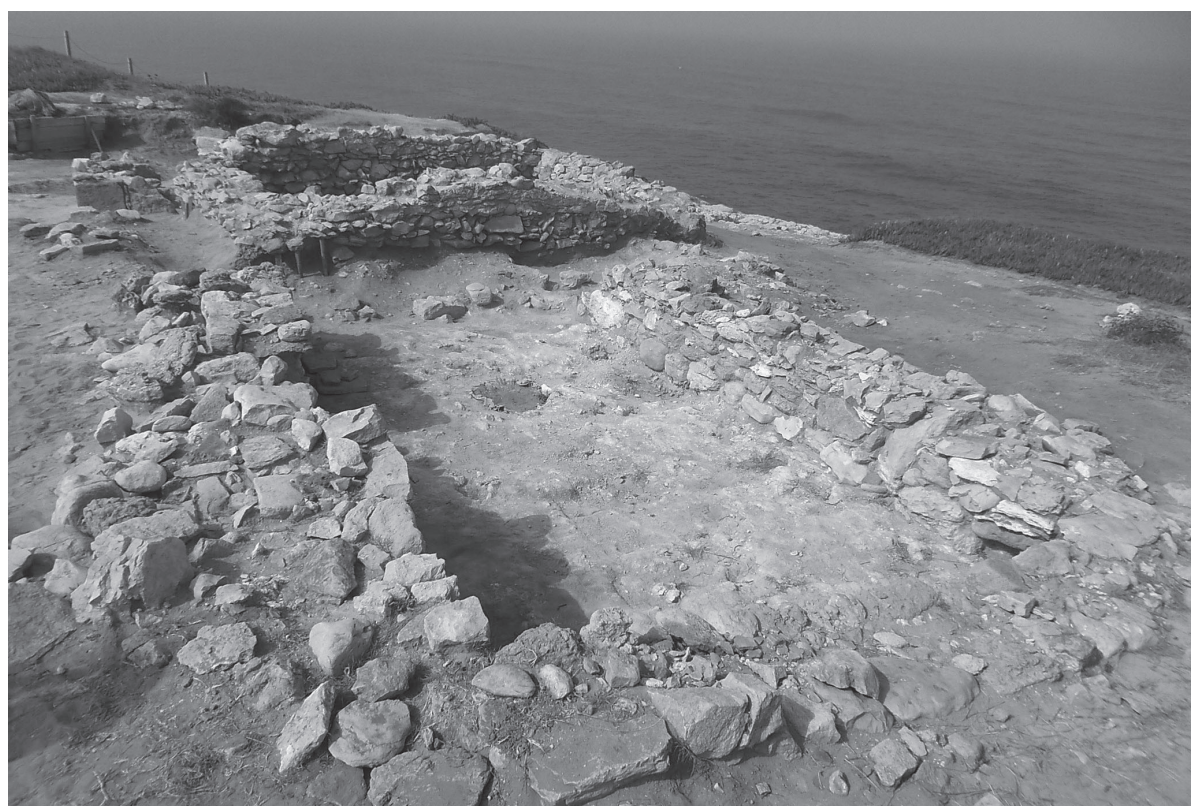

Fuente: Foto do autor. 
Um topónimo relevante, e que tem sido associado ao referido ribat, é Alconchel ou Ponta de Alconchel. No entanto, o referido topónimo encontra-se situado mais a Sul do local onde têm sido exumados os vestígios da antiga estrutura islâmica, dando nome à extremidade rochosa que faz fronteira entre a praia Pequena ${ }^{81}$, a Norte, e a praia Grande, a Sul (Figs. 2 e 3). José Pedro Machado interrogou-se sobre a possível relação deste topónimo com "concha" 82 . Se atendermos às enormes quantidades de conchas que têm sido identificadas no Alto da Vigia, e que em certas partes do terreno ainda são visíveis no solo, sendo que esses vestígios poderão estender-se mais para Sul, faria todo o sentido que o topónimo estivesse, de facto, relacionado com esse tipo de evidências que revelam a inclusão da vida marítima local no regime alimentar das pessoas que por ali passaram. Contudo, o topónimo Alconchel, de origem moçárabe e igualmente existente, por exemplo, em Évora e em Espanha, derivará de al-conciliu ${ }^{83}$, estando possivelmente ligado a um local de reunião humana, pelo que os arqueólogos que desenvolvem as escavações no Alto da Vigia crêem que o mesmo estará associado ao ribat ${ }^{84}$.

Dois dados bastante curiosos surgem numa carta da barra do Tejo e arredores de 1756: um forte edificado no outeiro que corresponderá à Ponta de Alconchel, bem como uma área de ancoradouro adjacente e que abarca o recorte costeiro alusivo à praia Pequena (Fig. 8). Se a representação for verdadeira, e estando-se perante uma área estratégica, não admira que na Ponta de Alconchel também tenham existido construções mais antigas que tenham precedido a fortificação que surge na carta. De facto, faz muito sentido que o território entre o Alto da Vigia e a Ponta de Alconchel, dominando espaços de ancoradouro, de desembarque e de acesso ao interior do território, tenha funcionado como um todo defensivo e sido ocupado em larga diacronia. Neste encadeamento de ideias, e crendo na possibilidade de que a presença humana se estendeu para Sul com a existência de estruturas ${ }^{85}$, a interpretação que sugere que o topónimo Alconchel aponta para um local de reunião é bastante plausível. Porém, a área da Ponta de Alconchel foi fortemente modificada pela acção do homem em tempos recentes, contrariamente ao espaço do Alto da Vigia que está a ser intervencionado, construindo-se edifícios que se sobrepuseram a possíveis estruturas anteriores. Resta, no entanto, pouco mais do que uma área com vegetação nessas imediações que não foi alvo de construções e que poderá um dia vir a revelar a existência de estruturas pétreas.

\footnotetext{
${ }^{81}$ Também referida como praia da Vigia na cartografia antiga.

${ }^{82}$ Machado, José Pedro. "Alconchel”, em Dicionário Onomástico Etimológico da Língua Portuguesa, 2. ed., vol. I (Lisboa: Livros Horizonte, 1993), p. 82.

${ }^{83}$ Gordón Peral, María Dolores. "De Toponimia Hispalense”, em Philologia Hispalensis, vol. II, fasc. 1, Sevilla, Universidad de Sevilla, 1987, p. 149; González Salgado, José Antonio. “Orígenes y clasificación de la toponimia mayor estremeña”, em Girón Alconchel, José Luís e Bustos Tovar, José Jesús de (coords.), Actas del VI Congreso Internacional de Historia de la Lengua Española, vol. 2 (Madrid: Universidad Complutense de Madrid, 2006), p. 1449.

${ }^{84}$ Numa outra interpretação, Adalberto Alves vê Alconchel como uma variante de Alcanchal, estando este topónimo relacionado com expressões como "o piso ou o solo difícil", "caminho difícil, com mau piso ou intransitável", Alves, Adalberto. "Alcanchal" e "Alconchel”, Op Cit., pp. 123 e 131).

${ }^{85}$ Oliveira Borges, Marco. "A defesa costeira no distrito de Lisboa durante o período islâmico. I-A área a ocidente da cidade de Lisboa”...
} 
Figura 8. Pormenor da área costeira de Colares.

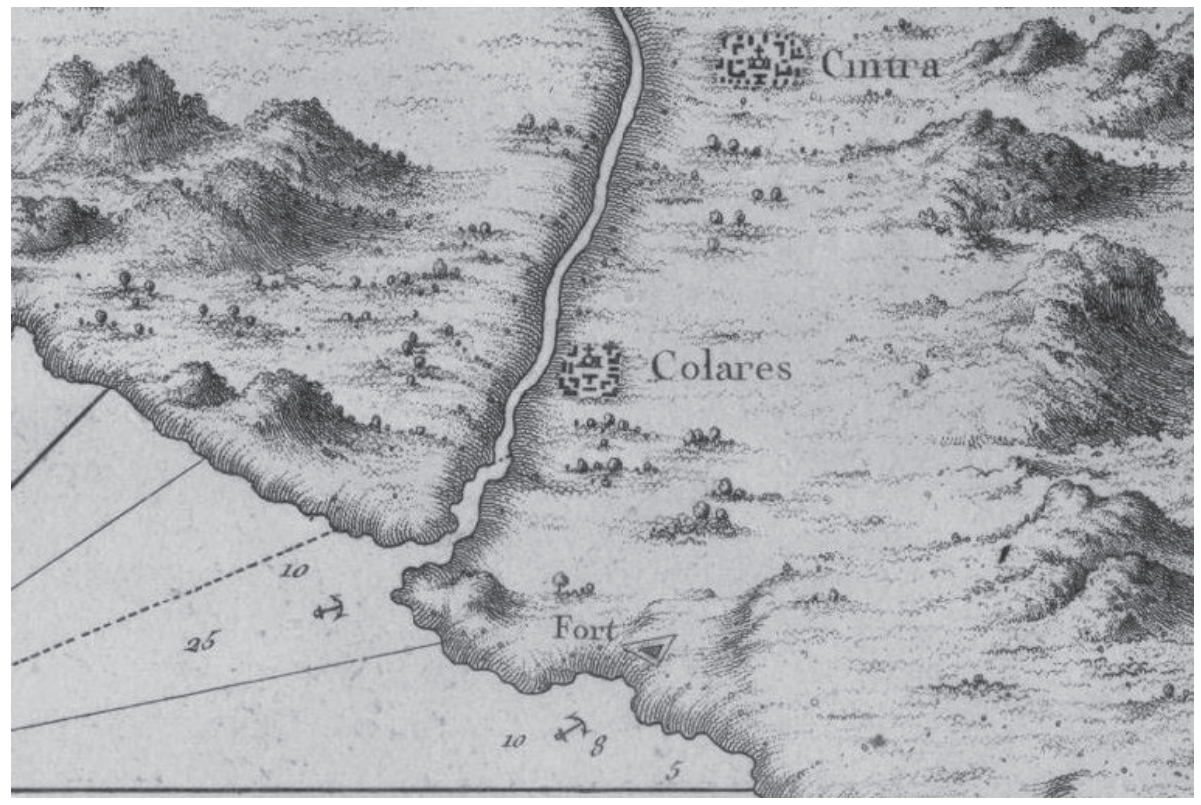

Fuente: BnF, M. Bellin, Plan du port de Lisbonne et des costes voisines ([Paris]: 1756).

\section{Atalaias e outros postos de vigia costeiros}

Estando Sintra dotada de uma linha costeira que permitia observar o movimento marítimo ao seu largo, que possibilitava o abrigo inimigo em pequenas enseadas e desembarques que facilitavam o acesso ao território, é natural que os ocupantes muçulmanos tenham aproveitado esses factores para a implantação de diversas estruturas de vigilância ${ }^{86}$. Acresce que a sua costa abrange o cabo da Roca, desde sempre um importante acidente geográfico para a navegação ${ }^{87}$, não esquecendo ainda a incapacidade de comunicação visual através do castelo dos Mouros em períodos de nevoeiro, pelo que outros postos alternativos e complementares ganhavam forma ao longo do litoral ${ }^{88}$. Por isso mesmo, a toponímia do concelho de Sintra fornece diversos étimos associados a contextos militares e relacionáveis com antigos postos defensivos e de observação oceânica.

Ligeiramente a Sul da foz da ribeira do Falcão, a cartografia indica o topónimo Vigia de Assafora. Seguindo o trecho costeiro meridional, um pouco a Sul do forte de Magoito e da ribeira da Mata, numa posição bastante elevada, surge o topónimo Vigia

\footnotetext{
${ }^{86}$ Oliveira Borges, Marco. "A defesa costeira do litoral de Sintra-Cascais durante o Garb al-Ândalus. I-Em torno do porto de Colares"..., pp. 111-113.

${ }^{87} \mathrm{Na}$ Antiguidade, entre outras denominações, era conhecido por promontório de Ofiússa. Avieno. Orla Marítima (Coimbra: Instituto Nacional de Investigação Científica/Centro de Estudos Clássicos e Humanísticos da Universidade de Coimbra, 1992) pp. 22 e 47, núm. 33.

${ }^{88}$ Oliveira Borges, Marco. "A defesa costeira do litoral de Sintra-Cascais durante o Garb al-Ândalus. I-Em torno do porto de Colares"..., pp. 111-113.
} 
da Mata. É muito provável que corresponda à Atalaia do Magoito, topónimo que surge na cartografia setecentista. Por sua vez, imediatamente a Sul da praia das Maçãs, local já abordado, surge o topónimo Vigia de Colares ou Alto da Vigia. Embora para os dois primeiros sítios não se saiba qual a natureza de ocupação humana, para este último a arqueologia mostrou que foi usado em larga diacronia.

Um local fulcral para as tarefas de vigilância e que era muito procurado pela navegação é o cabo da Roca. Junto a este sítio, onde entrou em funcionamento um farol em 1772, surge o topónimo Vigia da Roca e Cruzeiro do Facho, indicadores não apenas de um local de vigilância mas também de apoio à navegação nocturna. É muito provável que durante o Período Islâmico o cabo da Roca, área de forte vento e bastante perigosa para a navegação, já tivesse estruturas e que até pudessem ser mais antigas, dado este ser referido com importância na Antiguidade.

Um pouco mais para nascente do cabo da Roca, numa posição ainda mais elevada, temos a localidade da Azóia. Este topónimo deriva de az-zawiya, devendo ter surgido do desígnio de um edifício religioso existente naquela área serrana, provavelmente uma pequena ermida, mas que acumularia igualmente a função de posto de vigilância ${ }^{89}$, dando o alerta perante a aproximação inimiga. Nestas estruturas, situadas normalmente junto da costa e de vias de comunicação, também se deveria dar apoio aos desvalidos e a viajantes ${ }^{90}$. A Azóia da serra de Sintra vem referida durante a descrição da viagem da embaixada muçulmana enviada ao rei dos vikings após o ataque de 844 . A jornada foi efectuada por dois navios que partiram de Silves e que, ao chegarem ao "grande promontório que penetra no mar, limite de Espanha no extremo ocidental, e que é a montanha conhecida com o nome de Aluía [Azauia ou Azóia?], foram surpreendidos por uma tempestade" ${ }^{91}$. É de salientar que toda esta área da serra de Sintra era propícia à edificação de estruturas. Ainda hoje, ligeiramente a Norte da Azóia, existe uma localidade denominada Atalaia e que na micro-toponímia se subdivide em Atalaia de Baixo e Atalaia de Cima. A posição elevada e estratégica destes locais indicia a existência de antigos postos de vigilância costeira que poderão remontar aos séculos IX-X $\mathrm{X}^{92}$.

Vindo referido desde finais do século XIX como estando integrado no território de Cascais, mas pertencendo já ao concelho de Sintra, chegou a ser avançado que no sítio arqueológico do Espigão das Ruivas, ladeado do porto do Touro - este sim em território cascalense (Figs. 9 e 10)-, terá existido um farol para apoio à navegação usado em larga diacronia. No entanto, esta interpretação não deixa de levantar sérias dúvidas,

\footnotetext{
${ }^{89}$ Picard, Christophe. Le Portugal musulman..., núm. 47, p. 62.

${ }^{90}$ Catarino, Helena, Op Cit., p. 263.

${ }^{91}$ A possível identificação do termo "Aluía” com “Azóia” foi levantada por Borges Coelho, António. Op Cit., pp. 172 e 204, núm. 72, sendo posteriormente aclarada por Catarino, Helena, Op Cit., p. 264, reportando-se a autora à localidade da serra de Sintra com o mesmo topónimo e que está junto ao cabo da Roca.

92 Picard, Christophe. L'océan Atlantique musulman. De la conquête arabe à l'époque almohade. Navigation et mise en valeur des côtes d'al-Andalus et du Maghreb occidental (Portugal-Espagne-Maroc) (Paris: Maisonneuve et Larose, 1997), p. 92; Oliveira Borges, Marco. "A defesa costeira do litoral de Sintra-Cascais durante o Garb al-Ândalus. I-Em torno do porto de Colares”..., pp. 110-112.
} 
sendo necessários mais olhares sobre o_assunto ${ }^{93}$. A intervenção arqueológica realizada no local, em 1991, permitiu detectar vestígios de uma estrutura pétrea e materiais da Idade do Ferro, do Período Romano, do Período Visigótico e do Período Islâmico ${ }^{94}$, se bem que ainda não tenham sido estudados e publicados na sua totalidade. Em todo o caso, é de crer que no Espigão das Ruivas tenha existido uma pequena casa-abrigo para apoio à navegação, podendo ter funcionado como local de sinalização do porto do Touro aos navegantes, bem como de posto de vigia.

Quanto a este exíguo porto, em actividade igualmente durante o Período Islâmico, é muito provável que tenha sido usado como local de descaminho e contrabando de mercadorias em larga diacronia ${ }^{95}$. Ao mesmo tempo, e olhando para os casos do cabo da Roca e da enseada de Assentiz, locais estratégicos, muito próximos do referido porto e que foram usados por corsários e piratas ao longo dos séculos, é bem provável que a sua área marítima imediata tenha constituído igualmente um espaço de espera para se praticarem ataques contra a navegação em trânsito, pelo menos durante a Idade Moderna ${ }^{96}$.

O porto do Touro ainda vinha referido na cartografia dos séculos XVII-XIX, se bem que grafado de outra forma. Numa carta do atlas da Península Ibérica de Pedro Teixeira de 1634 (fig. 9), por exemplo, surge como "porto do Guincho", tendo representados dois navios ao seu largo, ainda que a linha costeira onde se encontra surja representada de forma bastante fantasiada. Fica por saber se na área imediata ao porto do Touro, local onde foram observados diversos fragmentos de cerâmica à superfície (incluindo de faiança) e onde existem ruínas de edifícios - geralmente atribuídos à construção de pescadores em tempos mais recentes -, existiu povoamento antigo, até mesmo relativo ao Período Islâmico, cenário muito provável face à utilização do Espigão das Ruivas desde a Idade do Ferro ${ }^{97}$. No entanto, somente futuras prospecções arqueológicas e possíveis escavações poderão vir a esclarecer as dúvidas que persistem. Acrescente-se a isto a necessidade de trabalhos de prospecção geofísica na área marítima imediata ao porto do Touro e nas enseadas das proximidades.

O território do actual concelho de Cascais, outrora na dependência de Sintra, também teve os seus postos de vigia durante a ocupação islâmica, sendo que o porto cascalense, que tem sido associado ao almirante muçulmano Khashkhash (século IX) ${ }^{98}$, estaria em

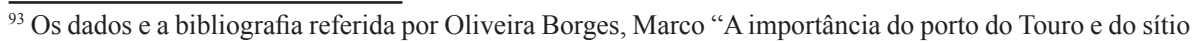
arqueológico do Espigão das Ruivas (Cascais) entre a Idade do Ferro e a Idade Moderna”, em História. Revista da FLUP, IV sér., vol. 6, Porto, Faculdade de Letras da Universidade do Porto, 2016, pp. 161-182.

${ }^{94}$ Cardoso, Guilherme, Miranda, Jorge e Teixeira, Carlos A. Registo fotográfico de Alcabideche e alguns apontamentos histórico-administrativos (Alcabideche: Junta de Freguesia de Alcabideche, 2009), pp. 29-35 e 390-394.

${ }^{95}$ Oliveira Borges, Marco, Op Cit., pp. 177-178.

${ }^{96}$ Oliveira Borges, Marco. "Portos e ancoradouros do litoral de Sintra-Cascais. Da Antiguidade à Idade Moderna (I)"..., pp. 162-164; “A importância do porto do Touro e do sítio arqueológico do Espigão das Ruivas (Cascais) entre a Idade do Ferro e a Idade Moderna”..., p. 180.

${ }^{97}$ Ibid., p. 175.

${ }^{98}$ Oliveira Borges, Marco e Condeço de Castro, Helena "O navegador muçulmano Khashkhash e a possível ligação com o topónimo Cascais: problemas e possibilidades”, em Arquivo de Cascais, núm. 14, Cascais, Câmara Municipal de Cascais, 2015, pp. 6-29.
} 
contacto visual e comunicação permanente com as estruturas de alerta sintrenses. É muito provável que nesse período já tivesse alguma importância para escoar a produção de Sintra, ao mesmo tempo que deveria prestar apoio às actividades militares navais da região, tal como aconteceu em séculos posteriores ${ }^{99}$.

Para além das estruturas que estariam dispostas ao longo da costa, existiam postos militares edificados mais para o interior. Um pouco mais para Leste, para a região entre Lisboa e Sintra, al-Himyari refere a existência de uma montanha usada antigamente como reduto fortificado ${ }^{100}$. Pelas indicações deixadas, esse local tem sido identificado como sendo Monte Suímo. Recentemente, neste local foram detectados fragmentos de telhas alto-medievais/islâmicas e vestígios de uma antiga estrutura pétrea que poderá corresponder às ruínas da fortificação referida por al-Himyari ${ }^{101}$. Embora não se saiba qual o tipo de fortificação que aqui deverá ter existido, é perceptível a razão da implantação de uma estrutura defensiva neste local. Situado na serra da Carregueira, Monte Suímo é uma colina de forma arredondada com $291 \mathrm{~m}$ de altura, constituindo o maior relevo do conjunto de elevações desta serra. A sua localização privilegiada permite obter uma visão de quase $360^{\circ}$ dos arredores, com vistas para Lisboa, estuário do Tejo, para toda a Península de Setúbal até à serra da Arrábida e para o Atlântico, sendo apenas interrompidas pelo perfil dominante da serra de Sintra ${ }^{102}$.

Figura 9. Pormenor da costa de Sintra e Cascais numa carta do atlas da Península Ibérica de Pedro Teixeira, 1634. Destaque para o porto do Guincho, mais conhecido por porto do Touro ${ }^{103}$.

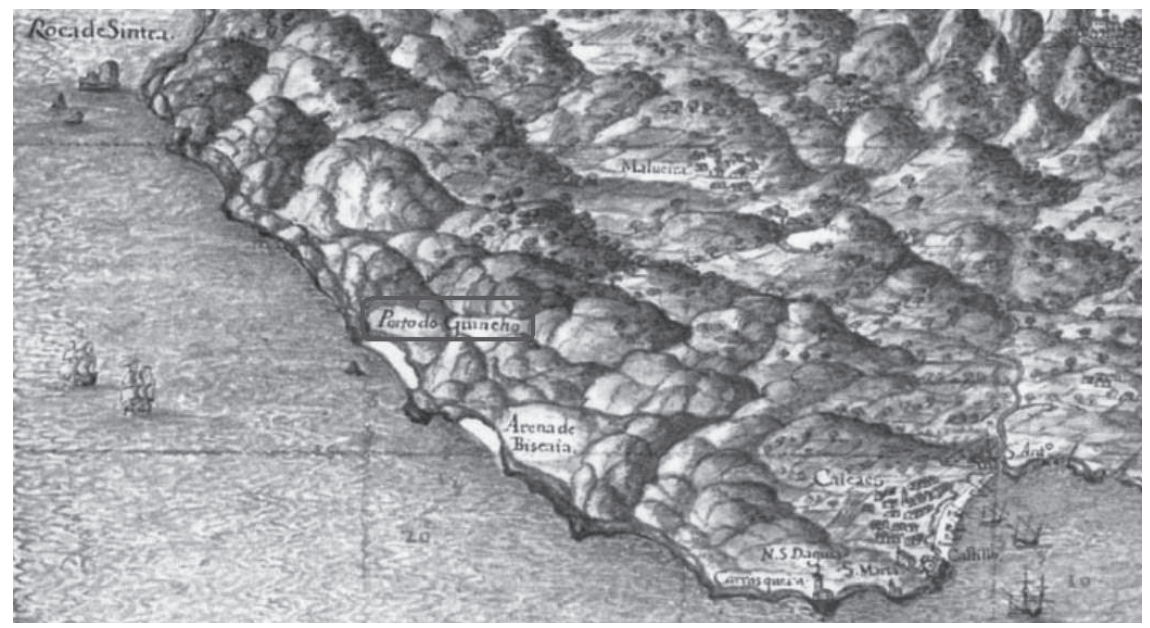

Fuente: Adaptado de Pereda, Felipe e Marías, Fernando (eds.). El Atlas del Rey Planeta. La «descripción de España y de las costas y puertos de sus reinos» de Pedro Teixeira (1634) (San Sebastián: Editorial Nerea, 2002).

\footnotetext{
${ }_{99}$ Os dados e a bibliografia aduzida por Oliveira Borges, Marco. "Aspectos de militarização e defesa costeira no Garb al-Ândalus: o caso de Cascais", em Revista Universitaria de Historia Militar (no prelo).

${ }^{100}$ Al-Himyari, Op Cit., p. 17; Coelho, António Borges, Op Cit., p. 47.

${ }^{101}$ Oliveira Borges, Marco. "A defesa costeira no distrito de Lisboa durante o período islâmico. I-A área a ocidente da cidade de Lisboa"...; "Aspectos de militarização e defesa costeira no Garb al-Ândalus: o caso de Cascais"...

${ }^{102}$ Cachão, M. et al. "A mina de granadas do Monte Suímo: de Plínio-o-Velho e Paul Choffat à actualidade”, em E-Terra. Revista Electrónica de Ciências da Terra, vol. XVIII, núm. 20, 2010, p. 2.

${ }^{103}$ Adaptado de Pereda, Felipe e Marías, Fernando (eds.). El Atlas del Rey Planeta. La «descripción de España y de las costas y puertos de sus reinos» de Pedro Teixeira (1634) (San Sebastián: Editorial Nerea, 2002).
} 
A importância estratégica do conhecimento do território na formação de um sistema...

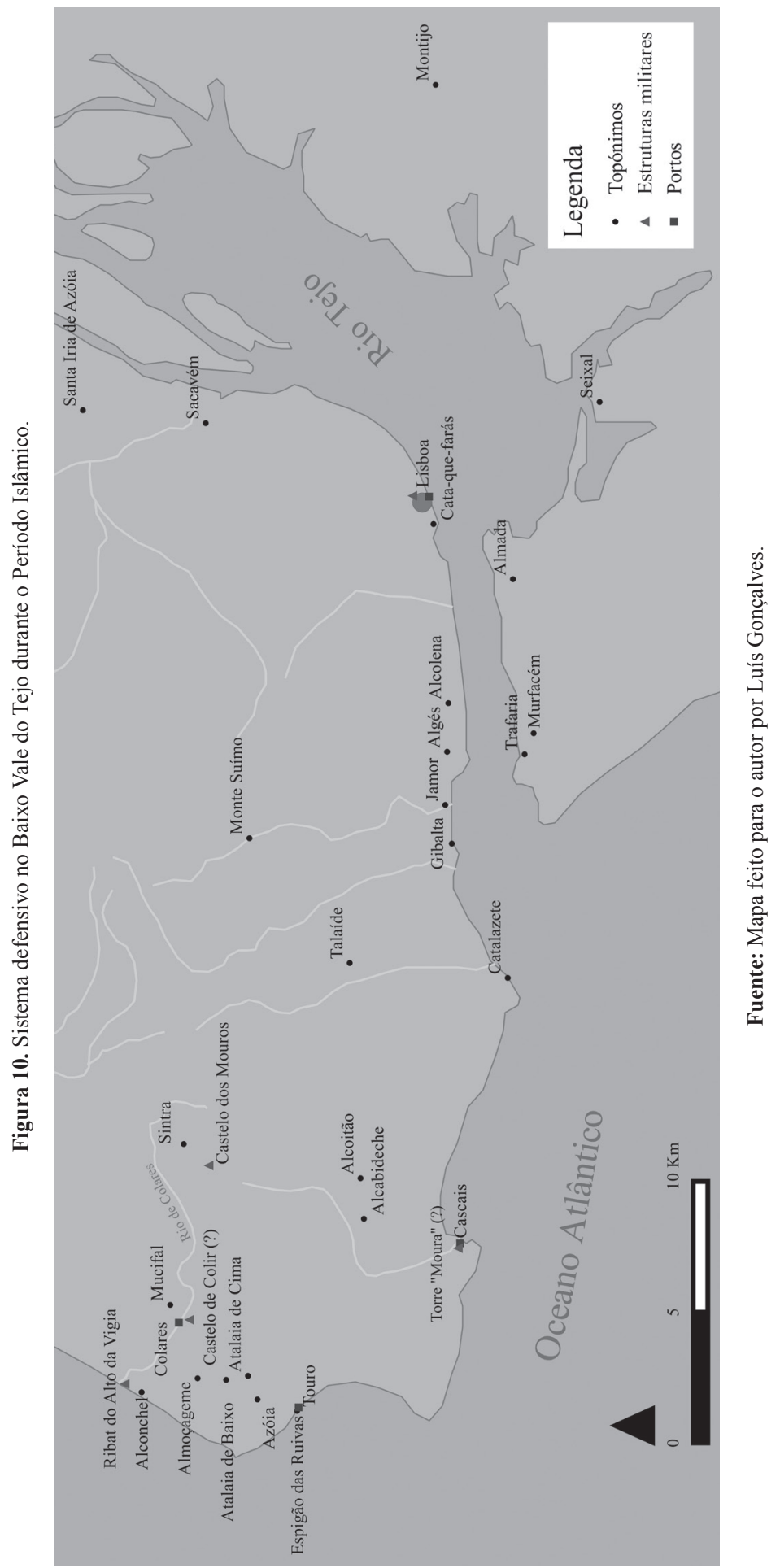


Todos estes locais e estruturas que temos vindo a referir, estejam inicialmente associados a iniciativas do poder central ou regional, revelam claramente a existência de um sistema defensivo e que a sua preparação obedeceu a um estudo aprofundado do território. No entanto, como era feita a gestão da defesa marítima? Ao mesmo tempo que o poder central tomava medidas defensivas, é possível que se deixasse aos governadores dos distritos (kuwar) alguma margem de manobra nas lides da defesa costeira ${ }^{104}$. Porém, parece que algumas zonas costeiras mais sensíveis, como era o caso das que estavam situadas perto de cabos ou promontórios (taraf, pl. atraf), chegaram a ser administradas independentemente dos distritos e dos seus governadores ${ }^{105}$. Poderá ter sido este, em certo momento, o caso de Sintra ${ }^{106}$. Este tipo de autonomia administrativa comprova-se para a Península de Setúbal, que chegou a ser considerada um distrito costeiro autónomo da jurisdição dos kuwar de Lisboa e Alcácer do Sal, pelo menos durante o califado omíada, estando dependente de um governador responsável pela coordenação da defesa e vigilância marítima e terrestre ${ }^{107}$.

Não é difícil imaginar, contudo, que as próprias rebeliões do mundo islâmico devam ter condicionado ao longo dos séculos a organização deste sistema de defesa costeira e até mesmo provocado a sua paralisação. Note-se que esta área, estando nas proximidades de Lisboa, cidade que viveu várias rebeliões contra o poder central e que, por vezes, se alastravam a outras cidades do al-Ândalus, parece ter estado em permanente insegurança. Na verdade, a área territorial entre Lisboa e Santarém gozou de uma certa autonomia face aos centros de decisão política do al-Ândalus até ao século XI, dando assim origem a uma zona de refúgio propícia a revoltas e que ficou marcada pelo aparecimento de dinastias locais autónomas ${ }^{108}$. Em 886, por exemplo, o wali de Lisboa revoltou-se contra Córdova. Como consequência, e para repor a ordem, o poder central enviou um exército por terra e uma frota de guerra (saída de Sevilha) a al-Ushbuna ${ }^{109}$.

\footnotetext{
${ }^{104}$ Branco Correia, Fernando. "A acção do poder político nas actividades portuárias e na navegação no ocidente islâmico. Alguns tópicos"..., p. 15. "Fortificações de iniciativa omíada no Gharb al-Andalus nos séculos IX e X-hipóteses em torno da chegada dos Majus (entre Tejo e Mondego)”..., p. 75.

${ }^{105}$ Picard, Christophe. Le Portugal musulman..., p. 62.

106 Ibid.

${ }^{107}$ Picard, Christophe e Ferreira Fernandes, Isabel Cristina, Op Cit., pp. 75-77; Picard, Christophe. Le Portugal musulman..., pp. 62 e 163; Pereda, Felipe e Marías, Fernando (eds.). "Les Ribats au Portugal à l'époque musulmane: sources et définitions"..., pp. 204-205; Alves Conde, Manuel Sílvio. "Sesimbra, sobre a Costa do Mar", em Arquipélago. História. Revista da Universidade dos Açores, 2ª sér., vol. VII, Ponta Delgada, 2003, p. 248; Santos Mendes, Francisco José dos. O Nascimento da Margem Sul. Paróquias, Concelhos e Comendas (1147-1385) (Lisboa: Edições Colibri, 2011), p. 27.

${ }^{108}$ Coelho, Catarina. "A ocupação islâmica do castelo dos Mouros (Sintra): interpretação comparada"..., p. 208; "O Castelo dos Mouros (Sintra)"..., p. 394. Uma revolta iniciada em Lisboa, em 808-809, teve repercussões a toda a faixa ocidental entre Coimbra e Beja. Entre as décadas de 860 e 880 o Ocidente da Península foi agitado por quatro rebeliões sucessivas, todas elas chefiadas por Abd al-Rahman Ibn Marwan Ibn Yunus, governador da marca de Mérida, que chegou a conquistar e saquear Lisboa após uma dessas rebeliões iniciada em 876. Oliveira Marques, A. H. de. "O «Portugal» islâmico", Op Cit., pp. 124-126. Em 889-890, deu-se uma nova revolta em Lisboa e nos territórios a Norte, "[...] o que mostra que o controlo por parte dos Marwânidas conhecia eclipses e tomadas de poder por outros magnates, ainda pouco conhecidos", Ibid.

${ }^{109}$ Garcia Domingues, José D. História Luso-Árabe. Episódios e Figuras Meridionais (Lisboa: Pró-Domo, 1945), p. 101; O Nacionalismo Luso-Árabe e a sua contribuição para a constituição de Portugal, sep. do XXIII Congresso Luso-Espanhol (Coimbra, 1-5 de Junho de 1956), VIII, Coimbra, 1957, p. 9, núm. 6.
} 


\section{Conclusão}

Sintra integrou o sistema defensivo do distrito de Lisboa, servindo de importante posto de observação oceânica que alertava aquela cidade e outros locais a Norte e a Sul, situação que se manteve em séculos posteriores e cuja tradição ficou preservada na memória toponímica. Para além disso, como centro populacional importante, terá estado dotada de estruturas que albergavam as forças que visavam defender e impedir o acesso directo de inimigos ao interior do seu território, embora até ao momento só exista uma confirmação arqueológica: a estrutura que está a ser escavada no Alto da Vigia.

Isto só foi possível mediante estudos pormenorizados do território e de uma articulação estratégica de conhecimentos, algo que terá sido ordenado não apenas pelo poder central mas também a nível regional e local. Na esteira de Yves Lacoste, colocar em prática um sistema defensivo implicou uma análise minuciosa das diferentes combinações geográficas, das relações entre os povoados, das estradas, dos cursos de água, dos portos, ancoradouros e de outras condições naturais como o próprio clima e o relevo. No entanto, não se quer com isto dizer que todos os postos defensivos e de alerta abordados funcionaram na mesma época. Um ponto a destacar é que alguns locais importantes já teriam sido utilizados em épocas anteriores, havendo inclusive uma readaptação de materiais pétreos no Período Islâmico, tal como se comprova no caso do Alto da Vigia. De enorme potencial arqueológico, é preciso averiguar locais, topónimos e as hipóteses explicativas que têm vindo a ser colocadas para o caso sintrense, não esquecendo as importantes ligações com diversos sítios dos concelhos de Mafra, Cascais, Oeiras, etc.

\section{Fontes}

\section{Fontes primárias}

\section{Arquivos}

BnF, M. Bellin, Plan du port de Lisbonne et des costes voisines. [Paris], 1756.

Carta chorographica dos terrenos em volta de Lisboa comprehendendo a principal parte do Tejo adjacente à sua foz, escala 1/100.000. Lisboa: Direcção dos Trabalhos Geodésicos do Reino, 1856-1866.

Carta Militar de Portugal, Colares (Sintra), escala 1/25.000, folha 415. Serviço Cartográfico do Exército, 1991.

Marques Gonçalves, Alexandre. Alto da Vigia (Colares, Sintra). Relatório dos trabalhos arqueológicos de 2013, 2014 [policopiado].

Jordão, Patrícia; Mendes, Pedro e Gonçalves, Alexandre. Alto da Vigia (Colares, Sintra). Relatório dos Trabalhos Arqueológicos [de 2008], 2009 [policopiado]. 
Marques Gonçalves, Alexandre . Escavação arqueológica do Alto da Vigia (ColaresSintra): Relatório da intervenção realizada em 2015, 2016 [policopiado].

\section{Livros}

Abenalcotía. Historia de la conquista de España de Abenalcotía el Cordobés. Seguida de fragmentos históricos de Abencotaiba, etc., trad. de Ribera, Don Julián. Madrid: Tipografía de la Revista de Archivos, 1926.

Al-Bakri, Abu Ubayd. Geografia de España (Kitab al-Masalik Wa-l-Mamalik), introd., trad, notas e índ, por Vidal Beltran, Eliseo. Zaragoza: Anubar, 1982.

Al-Himyari. Kitab ar-Rawd al-Mi 'tar, trad. por Maestro González, Mª Pilar. Valencia: Anubar, 1963.

Alves, Adalberto. Dicionário de Arabismos da Língua Portuguesa. Lisboa: Imprensa Nacional-Casa da Moeda, 2013.

Barros, João de. Chronica do Emperador Clarimundo, Donde os Reis de Portugal Descendem, quinta impressão, t. III. Lisboa: Na Officina de João António da Silva, 1791.

Borges Coelho, António. Portugal na Espanha Árabe, 3. a ed., rev. Lisboa: Editorial Caminho, 2008.

Caetano, Maria Teresa. Colares. Sintra: Câmara Municipal de Sintra, 2000.

Cardoso, Guilherme; Miranda, Jorge e Teixeira, Carlos A. Registo fotográfico de Alcabideche e alguns apontamentos histórico-administrativos. Alcabideche: Junta de Freguesia de Alcabideche, 2009.

Idrisi. Geografia de España. Valencia: Anubar, 1974.

Pereda, Felipe e Marías, Fernando (eds.). El Atlas del Rey Planeta. La «descripción de España y de las costas y puertos de sus reinos» de Pedro Teixeira (1634). San Sebastián: Editorial Nerea, 2002.

Picard, Christophe. Le Portugal musulman (VIII ${ }^{e}-X I I I^{e}$ siècle). L'Occident d'alAndalus sous domination islamique. Paris: Maisonneuve et Larose, 2000.

Rei, António. O Gharb al-Andalus al-Aqsâ na Geografia Árabe (séculos III h./IX d.C.-XI h./XVII d.C.). Lisboa: Instituto de Estudos Medievais, 2012.

Santanna, Frei Joseph Pereira de. Chronica dos Carmelitas da Antiga, e Regular Observancia Nestes Reynos de Portugal, Algarves, e seus Domínios, t. II. Lisboa: Na Officina dos Herdeiros de António Pedrozo Galram, 1751. 
A importância estratégica do conhecimento do território na formação de um sistema...

\section{Capítulos de livros}

Branco Correia, Fernando. "A acção do poder político nas actividades portuárias e na navegação no ocidente islâmico. Alguns tópicos”, em Solórzano Telechea, Jesús Angel e Viana, Mário (eds.). Economia e Instituições na Idade Média. Novas Abordagens. Ponta Delgada: Centro de Estudos Gaspar Frutuoso, 2013.

Branco Correia, Fernando. "Fortificações de iniciativa omíada no Gharb al-Andalus nos séculos IX e X-hipóteses em torno da chegada dos Majus (entre Tejo e Mondego)", em Ferreira Fernandes, Isabel Cristina (coord.), Fortificações e Território na Península Ibérica e no Magreb (séculos VI a XVI), vol. I. Lisboa: Edições Colibri/Campo Arqueológico de Mértola, 2013.

Cardim Ribeiro, José. “Ad Antiquitates Vestigandas. Destinos e itinerários antiquaristas nos campos olisiponenses ocidentais desde inícios a meados do século XVI", em González Germain, Gerard (coord.), Peregrinationes ad inscriptiones colligendas. Estudios sobre epigrafía de tradición manuscrita. Bellaterra: Universitat Autònoma de Barcelona, 2016.

Catarino, Helena. "Breve sinopse sobre topónimos Arrábida na costa portuguesa", em Franco Sánchez, Francisco (ed.), em La Rábita en el Islam. Estudios Interdisciplinares. Congressos Internacionals de Sant Carles de la Ràpita (1989, 1997). Sant Carles de la Ràpita/Alacant: Ajuntament de Sant Carles de la Ràpita/Universitat d'Alacant, 2004.

Coelho, Catarina. "Castelo de Sintra: evidências arqueológicas do quotidiano entre os séculos IX-XII", em Ferreira Fernandes, Isabel Cristina (coord.), Fortificações e Território na Península Ibérica e no Magreb (séculos VI a XVI), vol. II. Lisboa: Edições Colibri/Campo Arqueológico de Mértola, 2013.

Coelho, Catarina. "O castelo dos Mouros (Sintra)", em Ferreira Fernandes, Isabel Cristina (coord.), Mil Anos de Fortificações na Península e no Magreb (500-1500). Actas do Simpósio Internacional sobre Castelos. Lisboa: Edições Colibri, 2002.

João de Sousa, Maria. "The castelo dos Mouros, Sintra", em Portugal. Report and proceedings of the 157 15 Summer Meeting of the Royal Archaeological Institute in 2011. London: The Royal Archaeological Institute, 2012.

Oliveira Borges, Marco. "A defesa costeira do litoral de Sintra-Cascais durante a Época Islâmica. II-Em torno do porto de Cascais”, em Cunha, Ana; Pinto, Olímpia e Oliveira Martins, Raquel de (coords.), Paisagens e Poderes no Medievo Ibérico. Actas do I Encontro Ibérico de Jovens Investigadores em História Medieval. Arqueologia, História e Património. Braga: Centro de Investigação Transdisciplinar «Cultura, Espaço e Memória»/Universidade do Minho, 2014.

Oliveira Borges, Marco. “A defesa costeira no distrito de Lisboa durante o período islâmico. I-A área a ocidente da cidade de Lisboa", em Tente, Catarina, et al. (coords.), Lisboa Medieval: Gentes, Espaços e Poderes. Textos seleccionados do III Colóquio Internacional «A Nova Lisboa Medieval» (Lisboa, FCSHNOVA, 20-22 de Novembro de 2013). Lisboa: Instituto de Estudos Medievais (no prelo). 
Oliveira Borges, Marco. "Paisagem cultural marítima de Sintra: uma abordagem histórico-arqueológica", em Actas do I Colóquio Ibérico de Paisagem. O estudo e a construção da Paisagem como problema metodológico (no prelo).

Oliveira Borges, Marco. "Portos e ancoradouros do litoral de Sintra-Cascais. Da Antiguidade à Idade Moderna (I)", em Actas das Jornadas do Mar 2014. Mar: Uma onda de Progresso. Almada: Escola Naval, 2015.

Oliveira Marques, A. H. de "O «Portugal» islâmico", em Serrão, Joel e Oliveira Marques, A. H. de (Dir.), Nova História de Portugal, vol. II-Portugal das Invasões Germânicas à Reconquista. Lisboa: Editorial Presença, 1993.

Pereda, Felipe e Marías, Fernando (eds.). "Les Ribats au Portugal à l'époque musulmane: sources et définitions", em Ferreira Fernandes, Isabel Cristina (coord.), Mil Anos de Fortificações na Península e no Magreb (500-1500). Actas do Simpósio Internacional sobre Castelos. Lisboa: Edições Colibri, 2002.

\section{Publicações periódicas}

Cachão, M., et al. "A mina de granadas do Monte Suímo: de Plínio-o-Velho e Paul Choffat à actualidade", em E-Terra. Revista Electrónica de Ciências da Terra, vol. XVIII, núm. 20, 2010.

Carvalho, Sérgio Luís de. "A presença árabe em Sintra durante a Idade Média”, em História, núm. 101, 1987.

Coelho, Catarina. "A ocupação islâmica do castelo dos Mouros (Sintra): interpretação comparada”, em Revista Portuguesa de Arqueologia, vol. III, núm. 1, 2000.

Coelho Pimenta, Frederico. "Subsídios para o estudo do material anfórico conservado no Museu Regional de Sintra”, em Sintria, vols. I-II, t. I, 1982-1983.

Oliveira Borges, Marco. "A defesa costeira do litoral de Sintra-Cascais durante o Garb al-Ândalus. I-Em torno do porto de Colares", em História. Revista da FLUP, IV sér., vol. II, 2012.

Oliveira Borges, Marco. “A importância do porto do Touro e do sítio arqueológico do Espigão das Ruivas (Cascais) entre a Idade do Ferro e a Idade Moderna”, em História. Revista da FLUP, IV sér., vol. VI, 2016.

Oliveira Borges, Marco. "Aspectos de militarização e defesa costeira no Garb alÂndalus: o caso de Cascais”, em Revista Universitaria de Historia Militar (no prelo).

Oliveira Borges, Marco. "Em torno da preparação do cerco de Lisboa (1147) e de uma possível estratégia marítima pensada por D. Afonso Henriques”, em História. Revista da FLUP, IV sér., vol. III, 2013. 
A importância estratégica do conhecimento do território na formação de um sistema...

Oliveira Borges, Marco e Condeço de Castro, Helena. "O navegador muçulmano Khashkhash e a possível ligação com o topónimo Cascais: problemas e possibilidades”, em Arquivo de Cascais, núm. 14, 2015, pp. 6-29.

\section{Teses}

Pires, Hélio. Incursões nórdicas no Ocidente Ibérico (844-1147): fontes, história e vestígios, (tese de doutoramento), UNL, 2012.

\section{Fontes secundárias}

\section{Livros}

Alarcão, Jorge de e Barroca, Mário (coords.). Dicionário de Arqueologia Portuguesa. Porto: Figueirinhas, 2012.

Avieno. Orla Marítima. Coimbra: Instituto Nacional de Investigação Científica/ Centro de Estudos Clássicos e Humanísticos da Universidade de Coimbra, 1992.

Christys, Ann. Vikings in the South. Voyages to Iberia and the Mediterranean. London/ New York: Bloomsbury Academic, 2015.

Garcia Domingues, José D. História Luso-Árabe. Episódios e Figuras Meridionais. Lisboa: Pró-Domo, 1945.

Garcia Domingues, José D. O Nacionalismo Luso-Árabe e a sua contribuição para a constituição de Portugal, sep. do XXIII Congresso Luso-Espanhol (Coimbra, 1-5 de Junho de 1956), VIII, Coimbra, 1957.

Gomes Barbosa, Pedro. Reconquista Cristã. Séculos IX-XII. Lisboa: Ésquilo, 2008.

Lacoste, Yves. A Geografia serve antes de mais para fazer a Guerra. Lisboa: Iniciativas Editoriais, 1977.

Machado, José Pedro. Dicionário Onomástico Etimológico da Língua Portuguesa, 2. ed., vol. I. Lisboa: Livros Horizonte, 1993.

Maquiavel, Nicolau. O Príncipe, introd. de Barreiros, José António. Lisboa: Editorial Presença, 2008.

Santos Mendes, Francisco José dos. O Nascimento da Margem Sul. Paróquias, Concelhos e Comendas (1147-1385). Lisboa: Edições Colibri, 2011.

Montero, Santiago. El Emperador y los ríos. Religión, ingeniería y política en el Imperio Romano. Madrid: Universidad Nacional de Educácion a Distancia, 2012.

Picard, Christophe. La mer et les Musulmans d'occident au Moyen Age (VIII ${ }^{\text {- }}$ XIII $^{e}$ siècle). Paris: Presses Universitaires de France, 1997. 
Picard, Christophe. L'océan Atlantique musulman. De la conquête arabe à l'époque almohade. Navigation et mise en valeur des côtes d'al-Andalus et du Maghreb occidental (Portugal-Espagne-Maroc). Paris: Maisonneuve et Larose, 1997.

\section{Capítulos de livros}

Azuar, "O contributo da Arqueologia para o estudo dos ribat-s do Al-Andalus", em Ribat da Arrifana. Cultura material e espiritualidade. Aljezur: Associação de Defesa do Património Histórico e Arqueológico de Aljezur, 2007.

Oliveira Borges, Marco. "Navegação comercial fluvio-marítima e povoamento no Ocidente do Municipium Olisiponense: em torno dos rios Lizandro (Mafra) e Colares (Sintra)", em Estudos em História da Antiguidade Clássica (no prelo).

Bramon, Dolors. "La Ràpita del Cascall al delta de 1'Ebre”, em Franco Sánchez, Francisco (ed.), em La Rábita en el Islam. Estudios Interdisciplinares. Congressos Internacionals de Sant Carles de la Ràpita (1989, 1997). Sant Carles de la Ràpita/ Alacant: Ajuntament de Sant Carles de la Ràpita/Universitat d'Alacant, 2004.

Carvalho, António Rafael e Wu, Chia-Chin. “A influência do oceano Atlântico/Bahr Uqiyanus al-A'zam na procura de Deus/Allah: uma reflexão, desde o Alentejo litoral/ sahil de al-Qasr, até à costa vicentina/sahil de Silves" (no prelo).

Epalza, Míkel de. "La Ràpita Islámica: Historia Institucional”, em Franco Sánchez, Francisco (ed.), em La Rábita en el Islam. Estudios Interdisciplinares. Congressos Internacionals de Sant Carles de la Ràpita (1989, 1997). Sant Carles de la Ràpita/ Alacant: Ajuntament de Sant Carles de la Ràpita/Universitat d'Alacant, 2004.

Ford, Ben. "Introduction", em Ford, Ben (ed.), The archaeology of maritime landscapes. New York: Springer, 2011.

Varela Gomes, Mário. "Ibn Qasi-Vida e obra do mestre sufi da Arrifana", em Ribat da Arrifana. Cultura material e espiritualidade. Aljezur: Associação de Defesa do Património Histórico e Arqueológico de Aljezur, 2007.

Varela Gomes, Rosa e Varela Gomes, Mário. "Ambiente natural e complexo edificado", em Ribat da Arrifana. Cultura material e espiritualidade. Aljezur: Associação de Defesa do Património Histórico e Arqueológico de Aljezur, 2007.

González Salgado, José Antonio. "Orígenes y clasificación de la toponimia mayor estremeña”, em Girón Alconchel, José Luís e Bustos Tovar, José Jesús de (coords.), Actas del VI Congreso Internacional de Historia de la Lengua Española, vol. 2. Madrid: Universidad Complutense de Madrid, 2006.

Macias, Santiago. "Archéologi islamique au Portugal: bilan et thèmes de recherche", em Sénac, Philippe (ed.), Histoire et archéologi de l'Occident musulman (VII ${ }^{e} X V^{e}$ siècles). Al-Andalus, Maghreb et Sicile. Toulouse: CNRS-Université de Toulouse-Le Mirail, 2012.

Macias, Santiago. "Resenha dos factos políticos", em Mattoso, José (Dir.), História de Portugal, vol. I-Antes de Portugal. [s.l.]: Editorial Estampa, 1997. 
A importância estratégica do conhecimento do território na formação de um sistema...

Mattoso, José. "Notas críticas às notas de fim de volume", em Herculano, Alexandre, História de Portugal. Desde o começo da Monarquia até o fim do Reinado de Afonso III, vol. I. Amadora: Livraria Bertrand, 1980.

\section{Publicações periódicas}

Alves Conde, Manuel Sílvio. "Sesimbra, sobre a Costa do Mar" em Arquipélago. História. Revista da Universidade dos Açores, $2^{\mathrm{a}}$ sér., vol. VII, 2003.

Azuar, R. "El ribât en al-Andalus: espacio y función", em Ilu. Revista de Ciencias de las Religiones. Anejos, vol. X, 2004.

Carvalho, António Rafael e Sousa, Vítor Rafael de. “A presença tardoromana e muçulmana na praia dos Coelhos. Notícia preliminar”, em Al-Madan, II sér., núm. 12, 2003.

Correia, J. Diogo. “Toponímia estremenha", em Estremadura. Boletim da Junta de Província, sér. II, núm. 44-46, 1957.

Gordón Peral, María Dolores. “De Toponimia Hispalense”, em Philologia Hispalensis, vol. II, fasc. 1, 1987.

Guedes Real, Mário, “Toponímia árabe da Estremadura”, em Estremadura. Boletim da Junta de Província, II sér., núm. 10, 1945.

Picard, Christophe e Ferreira Fernandes, Isabel Cristina. "La défense côtière à l'époque musulmane: l'exemple de la presqu'île de Setúbal”, em Archéologie Islamique, núm. 8, 1999.

Pires, Hélio. "Word from the South: a source for Morkinskinna?", em Viking and Medieval Scandinavia, núm. 10, 2014.

Varela Gomes, Rosa e Varela Gomes, Mário. "O Ribat da Arrifana (Aljezur, Algarve): resultados da campanha de escavações arqueológicas de 2002”, em Revista Portuguesa de Arqueologia, vol. VII, núm. 1, 2004.

\section{Teses}

Cavaco, Sandra. O arrabalde da Bela Fria. Contributos para o estudo da Tavira islâmica (dissertação de mestrado), Universidad de Aveiro-UA, 2011.

Lirola Delgado, Jorge. El poder naval de al-Andalus en la época del califato omeya (siglo IV hégira/X era cristiana), (tesis doctoral), vol. I, Universidad de Guanajuato-UG, 1991.

Oliveira Borges, Marco. O porto de Cascais durante a Expansão Quatrocentista. Apoio à navegação e defesa costeira, (dissertação de Mestrado), Universidad de Lisboa-UL, 2012.

Oliveira-Leitão, André de. Povoamento no Baixo Vale do Tejo: entre a territorialização e a militarização (meados do século IX-início do século XIV), (dissertação mestrado), Universidad de Lisboa-UL, 2011. 